\title{
Nordic checklist food contact materials
}

Declaration of compliance and supporting documentation

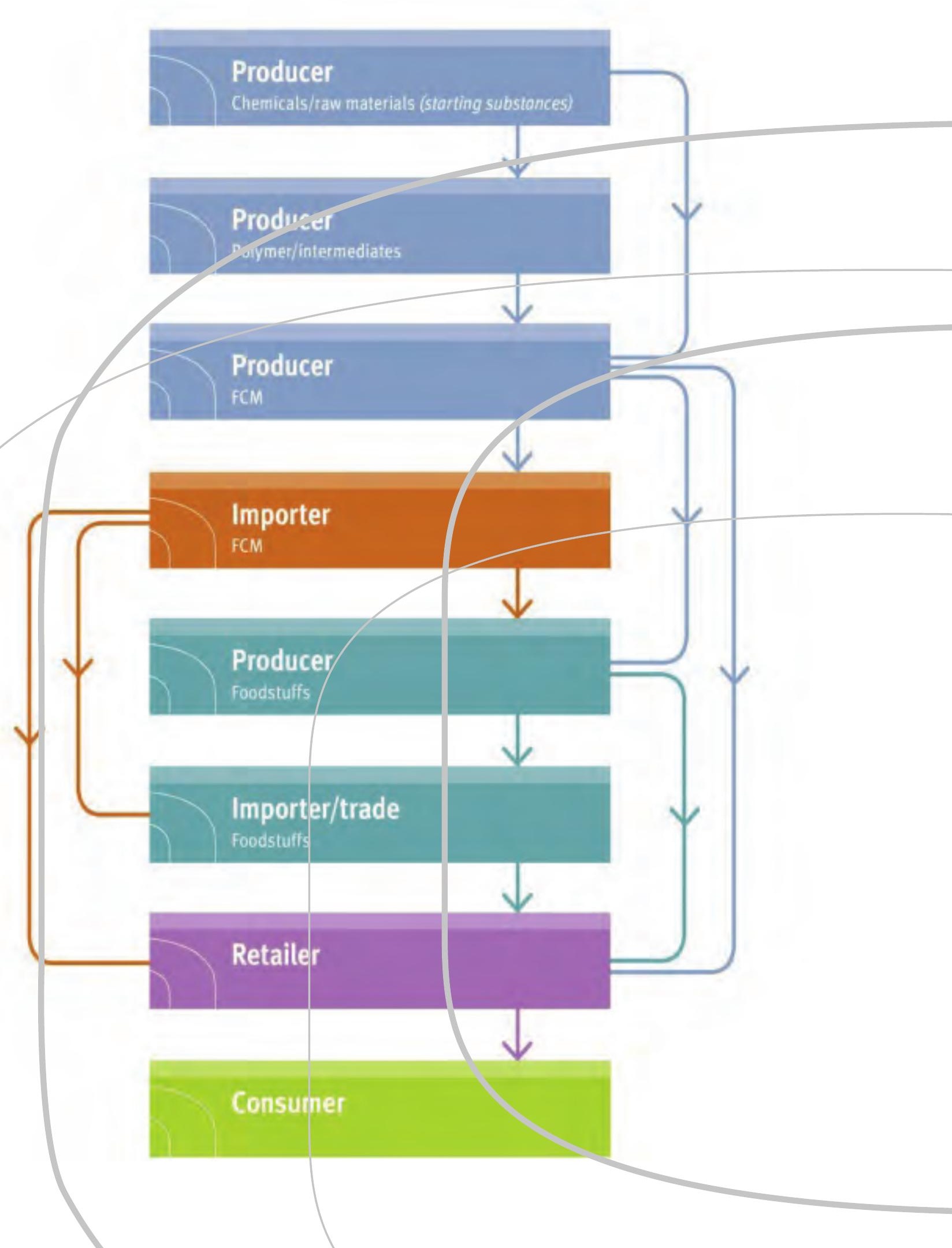



2 norden 



\section{Nordic checklist food contact materials}

Declaration of compliance and supporting documentation

Bente Fabech, Mette Christiansen, Christin Furuhagen, Katrín Guðjónsdóttir, Mette Holm, Julie Tesdal Håland, Ingibjörg Jónsdóttir, Pirkko Kostamo, Charlotte Legind, Ågot Li, Bjørg Mikkelsen, Åsa Lagerstedt Norström, Liisa Rajakangas, Signe Sem, Agneta Tollin and Merja Virtanen 
Nordic checklist food contact materials

Declaration of compliance and supporting documentation

Bente Fabech, Mette Christiansen, Christin Furuhagen, Katrín Guðjónsdóttir, Mette Holm, Julie Tesdal Håland, Ingibjörg Jónsdóttir, Pirkko Kostamo, Charlotte Legind, Ågot Li,

Bjørg Mikkelsen, Åsa Lagerstedt Norström, Liisa Rajakangas, Signe Sem, Agneta Tollin and Merja Virtanen

ISBN 978-92-893-4316-9 (PRINT)

ISBN 978-92-893-4318-3 (PDF)

ISBN 978-92-893-4317-6 (EPUB)

http://dx.doi.org/10.6027/TN2015-569

TemaNord 2015:569

ISSN 0908-6692

(C) Nordic Council of Ministers 2015

Layout: Hanne Lebech

Cover photo: Ophavsmand til omslagsfiguren

Print: Rosendahls-Schultz Grafisk

Printed in Denmark

This publication has been published with financial support by the Nordic Council of Ministers. However, the contents of this publication do not necessarily reflect the views, policies or recommendations of the Nordic Council of Ministers.

www.norden.org/nordpub

Nordic co-operation

Nordic co-operation is one of the world's most extensive forms of regional collaboration, involving Denmark, Finland, Iceland, Norway, Sweden, and the Faroe Islands, Greenland, and Åland.

Nordic co-operation has firm traditions in politics, the economy, and culture. It plays an important role in European and international collaboration, and aims at creating a strong Nordic community in a strong Europe.

Nordic co-operation seeks to safeguard Nordic and regional interests and principles in the global community. Common Nordic values help the region solidify its position as one of the world's most innovative and competitive.

\section{Nordic Council of Ministers}

Ved Stranden 18

DK-1061 Copenhagen $\mathrm{K}$

Phone (+45) 33960200

\section{www.norden.org}




\section{Contents}

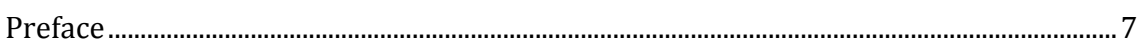

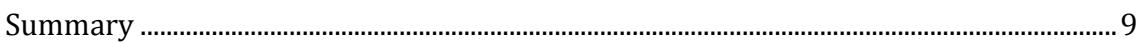

Abbreviations and definitions ...........................................................................................11

1. What are food contact materials? .................................................................................13

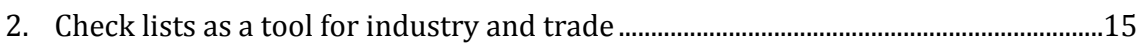

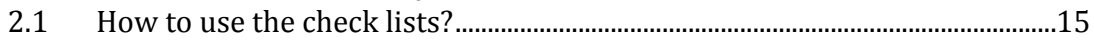

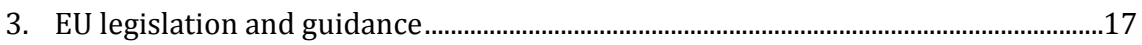

3.1 General requirements for all food contact materials .....................................17

3.2 Specific legislation in EU and national legislation .............................................18

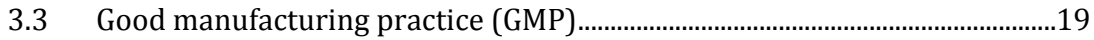

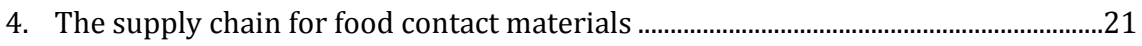

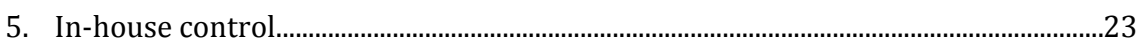

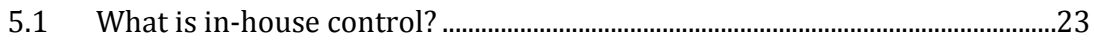

5.2 Documentation: Declarations of compliance and supporting

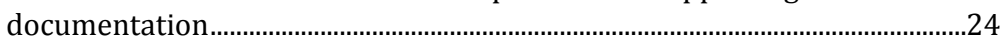

6. Supporting documentation ...............................................................................................27

7. Check lists as guidance for in-house control and declaration of compliance 29

7.1 General requirements and guidance for in-house control of all

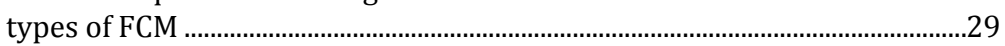

7.2 Producers and importers: Chemicals and other raw materials ......................30

7.3 Producers and importers: Intermediates like e.g. formulations of printing inks, surface coatings, lacquers, polymers or master batches .31

7.4 Producers and importers: Final food contact materials and articles ............31

7.5 Producers and importers of food (wholesalers) .................................................32

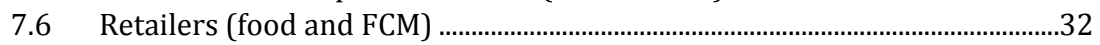

Sammendrag ....................................................................................................................33

Annex I. Legislation and guidance: Overview on EU and Nordic webpages etc............35

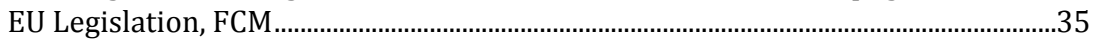

Useful webpages, EU and national ....................................................................................

Other EU Legislation with relevance to food contact materials .................................37

Guidance documents, EU, Nordic and others ...........................................................38

Annex II. Templates for declaration of compliance...........................................................4

Annex III. Supporting documentation in practice ............................................................55

Annex IV. Supporting documentation, analytical testing................................................59

Annex V. Decision tree for requirements for declaration of compliance and

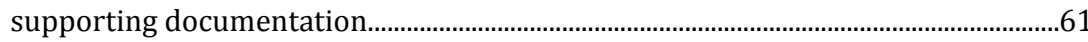





\section{Preface}

Food contact materials (abbreviated FCM in the following) are a potential source of contaminants in all types of food. Food is normally in contact with one or several types of FCM, e.g. process equipment and packaging. In-house control based on declaration of compliance and supporting documentation at the producers and importers are important prerequisites for the limitation of this contamination and to ensure compliance with the legislation.

The Nordic countries have long traditions of cooperation on food contact materials, as well as in many other areas. Denmark, Finland, and Sweden are members of the European Union, and Iceland and Norway are associated through the European Economic Agreement, EEA. Official opinions and public debate within one Nordic country will, in many cases, give rise to questions and debates in the other countries. Frequently, the call for uniform guidance and interpretations is brought forward, especially when the decisions and opinions within a certain area deviate from one another. The subject of Nordic checklist for food contact materials was dealt with in a project group under the Nordic Council of Ministers.

The project group consisted of the following persons:

\section{Denmark}

- Charlotte Legind, Mette Holm, Mette Christiansen and Bente Fabech, Danish Veterinary and Food Administration.

\section{Finland}

- Pirkko Kostamo, Finnish Food Safety Authority Evira.

- Liisa Rajakangas, Ministry of Agriculture and Forestry.

- Merja Virtanen, Regional State Administrative Agency.

\section{Faroe Islands}

- Bjørg Mikkelsen, Faroese Food and Veterinary Authority.

\section{Iceland}

- Katrín Guðjónsdóttir and Ingibjörg Jónsdóttir, Icelandic Food and Veterinary Authority. 


\section{Norway}

- Julie Tesdal Håland (chair person), Ågot Li, Grímur Ólafsson and Signe Sem, Norwegian Food Safety Authority.

\section{Sweden}

- Christin Furuhagen, Åsa Lagerstedt Norström and Agneta Tollin, Swedish National Food Agency. 


\section{Summary}

Documentation of compliance with the legislation is a corner stone in the control of food contact materials (FCM), including the public control. Inhouse control is an important pre-requisite to limit contamination from FCM and shall be based on the declaration of compliance and supporting documentation at the responsible business operators in the supply chain. Check points for elaboration of a declaration of compliance is part of the EU regulation on plastics, but evaluation of the final documentation is very complicated and further guidance to this work is needed.

FCM has been prioritised in the Nordic cooperation for many years in order to improve knowledge and control. The goal of this project was to develop a Nordic checklist on documentation of compliance for FCM and it was funded by the Nordic Working Group for Diet, Food and Toxicology (NKMT) under the Nordic Council of Ministers. The project has been carried out in synergy with another Nordic project on controlling FCM, funded by The Nordic Working Group for Food Safety and consumer information (NMF), also under the Nordic Council of Ministers. A draft of the Nordic checklist was used in the NMF project when controlling declaration of compliance and supporting documentation at establishments producing, importing or using plastic food contact materials. Feed back from the food inspections was used to finalize the draft guidance for declaration of compliance and supporting documentation.

FCM comprise a broad and complex area. Many different types of materials are used like e.g. plastic, paper, metal, wood, lacquer, adhesives and printing inks. The materials consist of single materials or combinations e.g. in complex multilayer materials. Furthermore, many different substances are used in the materials, e.g. monomers or additives like plasticizers, stabilizers, solvents and pigments.

The Nordic checklist contains several templates. The different templates provide check points on the minimum requirements for a declaration of compliance for all types of materials. The templates are meant to be used by industry and trade as guidance for drafting a declaration of compliance. Examples of supporting documentation for each point are also set out in this project. A decision tree is made to guide the responsible enterprise though the evaluation of a specific FCM. 
The responsibility for compliance with the legal requirements for FCM is placed at each link in the supply, like e.g. producer, user or trader (inter community trade and import from third countries, in relation to prepacked processed food) of FCM or food producers. Each link in the chain from the producers of chemicals and other raw materials to the food producers can use the templates for checking the declarations of compliance received from their suppliers, and for drafting declaration of compliances to their customers. Furthermore, the check lists are also meant to be tools for the public food and FCM inspection. These check lists should contribute in getting a harmonized approach for controlling the declaration of compliance and supporting documents in the Nordic countries. 


\section{Abbreviations and definitions}

\begin{tabular}{ll} 
Abbreviation & Abbreviated term \\
BfR & Bundesinstitut für Risikobewertung (German risk assessment institute) \\
CAS & Chemical abstracts service \\
CLP & Classification, labelling and packaging of chemicals and mixtures \\
DoC & Declaration of compliance \\
E-number & Code for food additives used in Europe \\
EFSA & European Food Safety Authority \\
FCM & Food contact material \\
FDA & US Food and Drug Administration \\
FL-number & Flavouring number \\
GML & Group migration limit \\
GMP & Good Manufacturing Practice \\
OML & Overall migration limit \\
SML & Specific migration limit \\
TDI & Tolerable daily intake \\
\hline
\end{tabular}

$\begin{array}{ll}\text { Definitions } & \\ \text { Adhesives } & \begin{array}{l}\text { Non-metallic substance capable of joining materials by surface bonding (adhesion), } \\ \text { and the bond possessing adequate internal strength (cohesion). }\end{array} \\ \text { Dual use additives } & \begin{array}{l}\text { Additives which are present in FCM and which are also listed as food additives or } \\ \text { flavourings in Regulations (EC) No 1333/2008 and (EC) No 1334/2008 and their } \\ \text { implementing measures. }\end{array} \\ \text { Printing inks } & \begin{array}{l}\text { Mixtures of colorants with other substances which are applied on materials to } \\ \text { form a print design on this material. }\end{array} \\ \text { Natural rubber } & \begin{array}{l}\text { Rubber not included in the definition of plastics according to regulation } 10 / 2011 . \\ \text { Low shear modulus materials, either natural or synthetic, made up of carbona- } \\ \text { ceous macromolecules, and characterised by long polymer chains arranged in a } \\ \text { three-dimensional flexible network held by chemical covalent cross-links. They } \\ \text { present, at service temperature and until their decomposition, elastic physical } \\ \text { properties which allow the material to be substantially deformed under stress and } \\ \text { recover almost its original shape when the stress is removed. The definition does } \\ \text { not cover thermoplastic elastomers. }\end{array}\end{array}$

1 Definitions are mainly taken from the "Union Guidelines on Regulation (EU) No 10/2011 on plastic materials and articles intended to come into contact with food." 



\section{What are food contact materials?}

Food contact materials and articles (FCM) comprise a broad and complex area. Many different types of materials are used like e.g. plastic, paper, metal, wood, lacquer, adhesives and printing inks. The materials consist of single materials or combinations e.g. in complex multilayer materials. Furthermore, many different substances are used in the materials, e.g. monomers or additives like plasticizers, stabilizers, solvents and pigments. An estimation of the total number of chemicals used is 10,000 's and only a small percentage of these chemicals have been assessed by the Scientific panels in the European Food Safety Authority (EFSA) for the use in FCM considering possible migration and potential safety effects on consumer health.

Food contact materials are a potential source of contamination of all types of food. Through all the phases of the production, food is normally in contact with one or several types of food contact materials, like e.g. packaging, including multilayer materials and process equipment.

Food contact materials shall comply with the legislation and in-house control in industry and trade is a tool to prevent violation of the legislation. In-house control is an important pre-requisite to limit contamination and shall be based on the declaration of compliance and supporting documentation at the producers and importers. 



\section{Check lists as a tool for industry and trade}

FCM produced and used shall comply with the legislation on FCM, and it is the responsibility of industry and trade to document this, see Chapter 3 and Annex I.

The check lists in the templates in Annex II provide check points on minimum requirements for the declaration of compliance for all types of materials. The templates are meant to be used by industry and trade as guidance for drafting a declaration of compliance. Examples of supporting documentation for each point are mentioned in Annex III (general) and IV (analysis). The decision tree in Annex V is meant for guiding the responsible enterprise through the evaluation of a specific FCM.

Each link in the chain from the producers of chemicals and other raw materials to the food producers can use the templates for checking the declarations of compliance received from their suppliers, and for drafting declaration of compliances to their customers. ${ }^{2}$ Furthermore, the check lists are also meant to be tools for the public food and FCM inspection.

\subsection{How to use the check lists?}

The templates in Annex II are set up for use in the elaboration of declarations of compliance following the FCM in the supply chain from suppliers to customers.

For example, a producer of chemicals (supplier) uses a template for drafting a declaration of compliance and sends it to the user (customer) of the chemical substances in the production of FCM. The customer use the same template to see what type of information the supplier should send.

2 The declaration of compliance shall follow the FCM in all steps of the supply chain excluding the retailer and the consumer. However, for ceramics, the DoC shall also be available at the retail stage. 
Furthermore, the templates can be used as check lists for the public food inspection when controls of the declaration of compliance are performed at the company.

To remind both business operators and the control authorities that business operators must document traceability in the supply chain, traceability is mentioned as a check point in the templates for drafting a declaration of compliance. According to article 17 in EU regulation $1935 / 2004$, business operators shall have in place systems and procedures to allow identification of the businesses from which and to which materials or articles are supplied. However, documentation of this system can be done independently of the declaration of compliance, e.g. in a separate document. 


\section{EU legislation and guidance}

The framework legislation on FCM covers general requirements for all types of FCM, which in their finished state:

- Are intended to be brought into contact with food; or

- Already are brought into contact with food and are intended for that purpose; or

- Can reasonably be expected to be brought into contact with food or to transfer their constituents to food under normal or foreseeable conditions of use.

For some types of materials, like plastics and ceramics, specific legislation exists.

Besides this harmonized legislation some countries, including some of the Nordic countries, have national legislation, e.g. on the chemical bisphenol A. Some of the Nordic countries (Denmark and Norway) also have legal requirements for a DoC for all types of materials, including cardboard and paper. In Finland, guidance concerning DoC is given and specified in the national FCM control guidance, i.e, not as a legal requirement.

\subsection{General requirements for all food contact materials}

General requirements covering all types of FCM concern among other safety, documentation and labeling and are given in the framework regulation. ${ }^{3}$

3 Regulation (EC) No 1935/2004 on materials and articles intended to come into contact with food is the framework regulation covering all types of FCM. 
General requirements in focus are according to article 3, 1:

"FCM shall - under normal and foreseeable conditions of use - not transfer their constituents into foodstuffs in quantities, which could:

- Endanger human health

- Bring about an unacceptable change in the composition of the foodstuffs or

- Bring about deterioration in the organoleptic characteristics thereof."

The other general requirement according to article 3,2 is:

"The labeling, advertising and presentation of FCM shall not mislead the consumers."

The regulation does not apply to FCM which are supplied as antiques, covering or coating materials for food (this covers cheese rinds, prepared meat products or fruits, which form part of the food and may be consumed together with this food). Nor does fixed public or private water supply equipment ${ }^{4}$ apply to the FCM regulation.

The EU regulation on control ${ }^{5}$ includes some obligations and possibilities for the member states. Part of this is the request for documentation at the enterprises, e.g. in article 8.

\subsection{Specific legislation in EU and national legislation}

In addition to the general legislation, EU has specific legislations on plastic (virgin and recycled), ceramics, active and intelligent packaging and regenerated cellulose. These specific legislations includes requirements for a declaration of compliance. For all other materials, a DoC is not a legal requirement, unless specified in national legislation.

The legislation is not described in details in this check list. An overview of webpages describing the EU and the Nordic legislation on FCM can be found in Annex I.

${ }_{4}^{4}$ The definition of fixed water supply equipment is under discussion in the EU.

${ }_{5}^{5}$ Control Regulation (EC) No 882/2004 of the European Parliament and of the Council of 29th April 2004 on official controls performed to ensure the verification of compliance with feed and food law, animal health and animal welfare rules. 


\subsection{Good manufacturing practice (GMP)}

GMP is a general requirement in the production of FCM and the intermediates used for the production of FCM. ${ }^{6}$ Intermediates are e.g. printing inks, surface coatings and master batches for production of plastic.

GMP requires that quality assurance, training of staff, flow charts, critical control points etc. must be documented in the production and handling of FCM. FCM producers must know the critical points in their production, e.g. in print shops the age of the UV-lamps is a critical point (see Annex I for some guidance documents including guidance on printing inks). In the food sector, the critical control points are named CCP's and are included in the hazard analysis named HACCP.

Guidance to industry and public control concerning GMP in the production of FCM is given by the Italian authorities. This guidance is not covering all types of materials yet, but can be useful for those sectors which are covered. ${ }^{7}$ The Italian guideline mentions Quality Assurance Systems and Quality Control Systems as minimum requirements (as the GMP legislation does). That corresponds to the Quality Management System ISO 9000 which includes both QA and QC.

GMP can be documented in different ways for example as HACCP or ISO 9000. A specific evaluation of the documentation in the ISO certification should be made.

\footnotetext{
${ }^{6}$ Regulation (EC) No 2023/2006 on good manufacturing practice.

${ }^{7}$ Italian guideline on GMP: http://www.iss.it/binary/publ/cont/11_37_web.pdf
} 



\section{The supply chain for food contact materials}

In general, food contact materials are produced from either chemical substances or raw materials of natural origin like wood fibres, cork or rubber.

The supply chain from the producer of the starting materials to the final consumer has many links. From producers of chemical substances or from the cultivation of trees to production of intermediates like printing inks, lacquers or master batches to production or import of final food contact materials (FCM). Furthermore, users of FCM in the food production, wholesales, retails or the consumer in private homes are also part of the supply chain (Figure 1).

Figure 1. An overview of the most typical parts of the supply chain. The arrows indicate some of the typical links in the supply chain

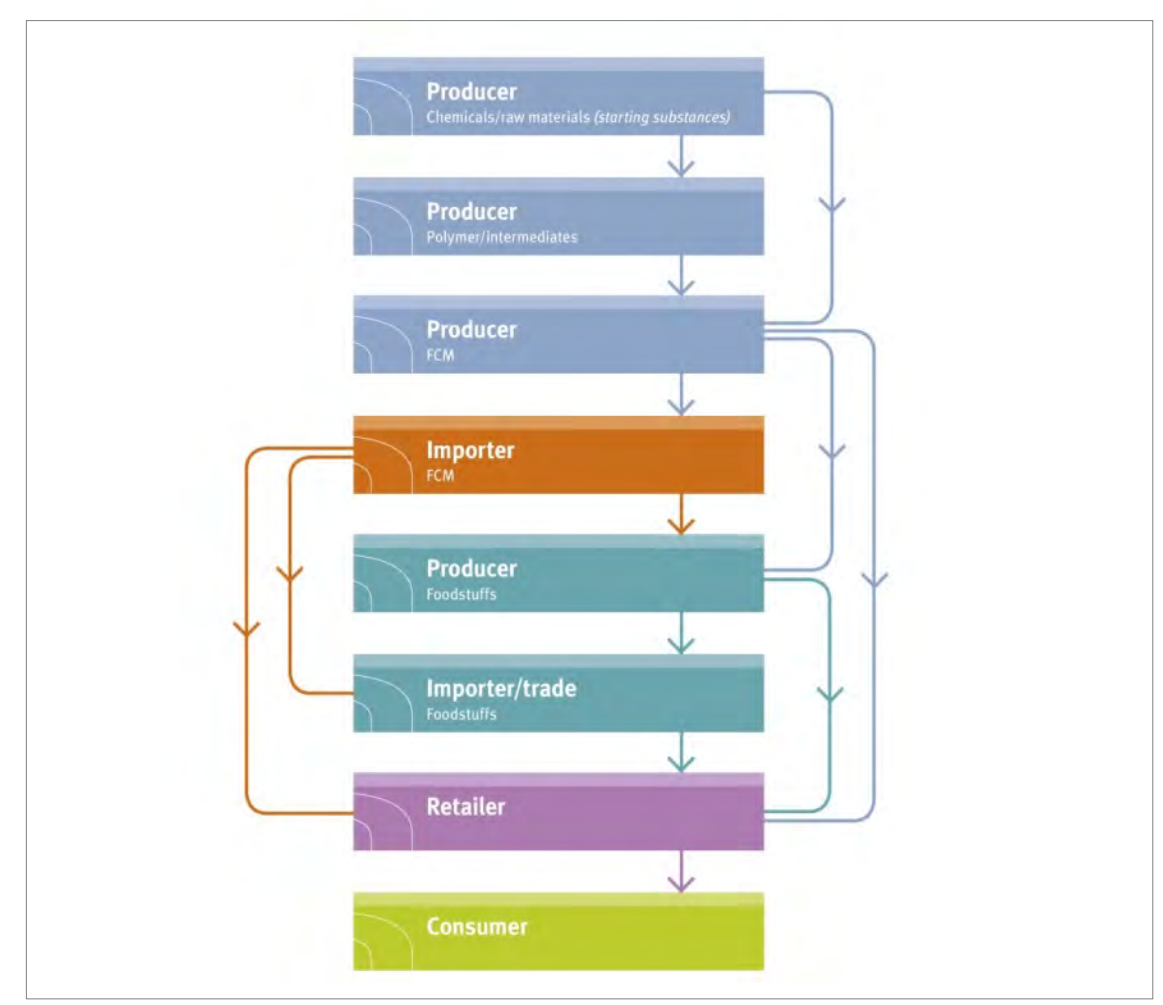





\section{In-house control}

The responsibility for compliance with the legal requirements ${ }^{8}$ for FCM is placed at each link in the supply chain, e.g. producer, user or trader (inter community trade and import from third countries, in relation to pre-packed processed food) of FCM or food producers.

GMP documentation is a part of the in-house control. Good manufacturing practice (GMP) means those aspects of quality assurance which ensure that materials and articles are consistently produced and controlled to ensure conformity with the rules applicable to them and with the quality standards appropriate to their intended use.

The starting point for establishing in-house control is having proper declarations of compliance and availability of supporting documentation from suppliers.

\subsection{What is in-house control?}

In-house control is defined as the systematic measures taken by the business operators to ensure that the legal requirements set out concerning food contact materials are fulfilled.

In-house control at the producer and importer of FCM (and food) is the basis for a safe production and import. The control of compliance includes verification that good manufacturing practice (GMP) has been followed in the production, and for importers, it includes knowledge of GMP at the supplier stage. Control of the activities should be based on identification of the critical points in the production and on declarations of compliance for raw materials and other ingoing materials from suppliers.

Who should have in-house control? All links in the production chain from the producers of the chemical substances and raw materials to the users in the food industry and the retailers should have in-house control.

${ }^{8}$ See also chapter 3 


\subsection{Documentation: Declarations of compliance and supporting documentation}

Compliance should be documented as part of the in-house control in industry and trade, see also Chapter 2.

The wording "documentation" covers both the declaration of compliance and its supporting documentation. The declaration of compliance (DoC) is documentation meant to be exchanged between the different links in the supply chain.

The declaration of compliance is documentation used among trade partners. The declaration of compliance is a written documentation stating that the food contact material complies with the rules applicable to it. To strengthen the coordination and responsibility of the suppliers at each stage of manufacture, including that of the starting substances, the responsible companies should document the compliance with the relevant legislation in a declaration of compliance which is made available to their customers. A declaration of compliance can include more than one material e.g. different colours of the same FCM, provided that the compliance assessment covers all variations.

The DoC can be regarded as a summary of the complete documentation for compliance. This complete documentation is named supporting documentation and it consists of all details, e.g. on analytical testing methods and method detection limits. Supporting documentation shall be available for authorities on request and is often used by industry and trade, when e.g. consultants are checking for compliance.

The responsible companies in industry and trade need to have the knowledge of or be acquainted with the specific areas essential to their assessment of the declaration of compliance.

The responsible companies in the supply chain for FCM shall have relevant knowledge of:

- the types of materials and combinations of materials (a tool for the consideration is given in Annex V)

- the legislation, including test conditions to be able to assess the reliability of the documentation (relevant links are in Annex I)

- good manufacturing practice in the production of the specific materials.

The starting point for the check lists for the establishment of appropriate in-house documentation is that all links in the chain from the producers of chemicals and other starting substance to the users (excluding consumers) are responsible for compliance of the final FCM. In-house documenta- 
tion is based on knowledge and trust between trade partners (templates for drafting a declaration of compliance are given in Annex II).

In particular, food producers should be aware of whether the FCM used are suitable for the specific types of food produced, including process and storage conditions like temperatures and contact time. Hence, the checklists mentioned above, are relevant for the food producers as well in order to be able to request relevant information from their FCM supplier in the declarations of compliance.

In general, a declaration of compliance should, as a starting point, be regarded as adequate in-house documentation for starting substances, intermediates, the final FCM and their compliance with the legislation. In-house control shall ensure that starting materials, including chemicals, intermediates and final FCM are complying with existing EU legislation and national legislation (if any). Furthermore, food producers and retailers shall ensure compliance of the FCM they are using, e.g. packaging, process equipment and storage containers. 



\section{Supporting documentation}

The declaration of compliance is a "summary" of the supporting documentation, which is the "full package" of background data.

Supporting documentation is defined in the plastic regulation ${ }^{9}$ as:

"Appropriate documentation to demonstrate that the materials and articles, products from intermediate stages of their manufacturing as well as the substances intended for the manufacturing of those materials and articles comply with the requirements of this Regulation shall be made available by the business operator to the national competent authorities on request. That documentation shall contain the conditions and results of testing, calculations, including modeling, other analysis, and evidence on the safety or reasoning demonstrating compliance."

For plastic, test conditions and rules for experimental demonstration of compliance are set out and specified in the plastic regulation.

The supporting documentation is sometimes regarded as confidential information and is not sent along in the supply chain. This documentation shall be given to authorities on request and the guidance timeframe is that this documentation should be made available for authorities within 1-2 weeks.

When authorities are requesting supporting documentation, it should be considered to specify, whether this supporting documentation is requested for all check points in the declaration of compliance, or for some points, e.g. information on migration and analysis.

Supporting documentation and documentation to the different check points listed in Annex II are given in Annex III and IV. In Annex IV, supporting documentation for analytical testing is dealt with separately, as there are many critical parameters which are relevant for evaluation of compliance.

The lists in Annex III and IV are not exhaustive and supplementary requests could be needed.

${ }_{9}$ Commission Regulation (EU) No 10/2011 of 14th January 2011 on plastic materials and articles intended to come into contact with food. 



\section{Check lists as guidance for in-house control and declaration of compliance}

The templates referred to in this chapter are given in Annex II.

The declaration of compliance follows FCM from the supplier to the costumer one step forward. Supporting documentation is a part of the responsible operators compliance work and is kept at each step as documentation. The declaration of compliance and supporting documentation shall be available for authorities on request.

It is important that the DoC can be linked to the product which it applies to.

\subsection{General requirements and guidance for in-house control of all types of FCM}

All types of food contact materials shall comply with some general requirements. Information on the points in template no. 1 is not necessarily required to be found in a DoC, but are requirements that must be in place when issuing a DoC. These requirements should be documented by using this template.

In general, the types of enterprises can be quite complex. In the following six types of enterprises are listed. A specific evaluation must be done in order to see which type of responsibility each enterprise has. 


\subsection{Producers and importers: Chemicals and other raw materials}

Chemical substances and other raw materials produced and sold for the production of FCM shall have documentation for compliance with the requirements set in the framework regulation and the relevant specific measures in other regulations. The producers of chemical starting substances are not covered by the GMP regulation. ${ }^{10}$

This group of enterprises covers the national producers, producers in the EU and importers of starting substances and raw materials:

- The general requirements should be documented by using template no. 1.

- Additionally, the requirements for chemicals should be documented by using template no. 2 .

The raw materials from natural origin like natural rubber and wooden fibers also are starting substances used in the production of e.g. paper and board. These components of natural origin shall comply with the requirements in the framework regulation, article 3 :

- The general requirements should be documented by using template no. 1.

- In addition, the requirements for the materials should be documented by using template no. 3 .

10 Commission Regulation (EC) No 2023/2006 of 22nd December 2006 on good manufacturing practice for materials and articles intended to come into contact with food. 


\subsection{Producers and importers: Intermediates like e.g. formulations of printing inks, surface coatings, lacquers, polymers or master batches}

Producers of intermediates like e.g. formulations of printing inks have the responsibility of using chemicals, for which a risk assessment is available, and to produce products, which will comply with the legislation when used in accordance with guidance or instructions of use given to the user.

Producers cover the national producers of FCM intermediates, producers of FCM intermediates in the EU and importers of intermediates for the production of FCM:

- The general requirements should be documented by using template no. 1.

- In addition, the requirements for the intermediates should be documented by using template no. 4 .

\subsection{Producers and importers: Final food contact materials and articles}

Producers of final FCM are producing the FCM from the chemical raw materials and/or from intermediates. Materials can be suitable for contact with a wide variety of food under many different conditions of use, while others can have a limited area of use. The FCM shall comply with the legislation, e.g. it must not cause deterioration in the organoleptic properties of the food.

Producers and importers cover the national producers, producers in the EU and importers of FCM into EU from third countries. Retailers that produce or import FCM are also covered by this group:

- The general requirements should be documented by using template no. 1.

- In addition, the requirements for FCM should be documented by using template no. 5 . 


\subsection{Producers and importers of food (wholesalers)}

The food producing industry (national and within the EU) is responsible for ensuring that the FCM they use is in compliance with the legislation on FCM. Documentation in this link of the supply chain shall address the specific conditions of use, e.g. the specific types of food it can be used in contact with. The food business operator should have a dialog with the supplier of FCM on this.

In addition to the food producers, any operator (wholesaler or retailer), who imports pre-packed food into the EU from third countries is also covered by this group and the FCM of pre-packed food shall comply with the EU legislation.

These business operators are not legally obliged to issue a DoC to their customers. However, the food producer must have a DoC from their supplier of FCM. To control the content of the received DoC, template no. 1 and template no. 5 should be used.

\subsection{Retailers (food and FCM)}

Retailers consist of many different types of companies. They are handling, processing and storing food at the point of sale or delivery to the final consumer, and include distribution terminals, catering operations, factory canteens, institutional catering, restaurants and other similar food service operations, shops, supermarket distribution centers and wholesale outlets. Retailers selling FCM to the consumers are also included in this group. These business operators shall not issue a DoC:

- Retailers with production of food (e.g. a baker or a butcher) are regarded as producers of food and should have the declaration of compliance from their supplier of FCM according to the requirements in template no. 1 and template no. 5.

- The retailer with food production should especially focus on traceability, labeling and restrictions of use.

- Retailers selling pre-packed food are not requested to have documentation for the FCM. Importers of pre-packed food are covered in 7.5.

- Retailers selling FCM (no import) should have traceability, instructions of use and labeling. As an exception, retailers selling ceramics should have the declaration of compliance. Importers of FCM are covered in 7.4. 


\section{Sammendrag}

Ved kontroll av matkontaktmaterialer, inkludert offentlig tilsyn, er det helt avgjørende at det kan dokumenteres at regelverket er oppfylt. Internkontroll er en viktig forutsetning for å begrense forurensning av maten fra matkontaktmaterialene og skal baseres på samsvarserklæringen og bakgrunnsdokumentasjon hos de ansvarlige virksomhetene i forsyningskjeden. Sjekkpunkter for utarbeidelse av samsvarserklæring er en del av EUs regelverk på plastmaterialer, men det å vurdere sluttdokumentasjonen er svært komplisert og det er nødvendig med ytterligere veiledning.

For å få bedre kunnskap og kontroll med produksjon og omsetning av matkontaktmaterialer, har det nordiske samarbeidet prioritert dette fagområdet i flere år. Målet med dette prosjektet var å utvikle en nordisk sjekkliste for dokumentasjon av samsvar for matkontaktmaterialer. Arbeidet har blitt finansiert av Nordisk arbeidsgruppe for kosthold, mat og toksikologi (NKMT) under Nordisk ministerråd. Prosjektet har vært utført i et samarbeid med et nordisk kontrollprosjekt på matkontaktmaterialer. Dette prosjektet har blitt finansiert av Nordisk arbeidsgruppe for matforvaltning og forbrukerinformasjon (NMF), også under Nordisk Ministerråd. Et utkast til den nordiske sjekklisten ble brukt i NMF-prosjektet der fokuset var kontroll av samsvarserklæringen og bakgrunnsdokumentasjon hos virksomheter som produserer, importerer eller bruker matkontaktmaterialer av plast. Tilbakemeldinger fra næringsmiddelinspektørene i kontrollprosjektet ble brukt til å ferdigstille den nordiske sjekklisten for samsvarserklæringer og bakgrunnsdokumentasjon.

Matkontaktmaterialer er et bredt og komplekst område. Mange forskjellige typer av materialer er omfattet, som for eksempel plast, papir, metall, tre, lakk, lim og trykkfarger. Materialene består av enkle materialer eller materialer i kombinasjoner, f. eks i komplekse flerlagsmaterialer. I tillegg brukes det mange forskjellige stoffer i materialene. Eksempler er monomerer eller additiver som plastmykgjørere, stabilisatorer, løsningsmidler og pigmenter.

Den nordiske sjekklisten inneholder flere maler. De ulike malene har sjekkpunkter med minimumskrav til samsvarserklæring for alle typer materialer. Malene er ment å bli brukt av industri og handel som veiled- 
ning ved utarbeidelse av samsvarserklæring. Eksempler på underliggende dokumentasjon for hvert punkt er også gitt i dette prosjektet. Et beslutningstre er laget for å veilede ansvarlig virksomhet gjennom en vurdering av et bestemt matkontaktmateriale.

Ansvaret for at matkontaktmaterialer er i samsvar med regelverket er plassert hos hvert ledd i verdikjeden, som for eksempel produsenter av matkontaktmateraler og virksomheter som bruker eller omsetter (samhandel og import fra tredjestater, i forhold til ferdigpakket bearbeidet mat) matkontaktmaterialer eller matvarer. Hvert ledd i kjeden, fra produsenter av kjemikalier og andre råvarer til matprodusenter, kan bruke malene for å sjekke samsvarserklæringene fra sine leverandører og for å utarbeide samsvarserklæringer til sine kunder. I tillegg er sjekklistene også ment å være verktøy for myndighetene i deres tilsyn med matkontaktmaterialer. Disse sjekklistene skal bidra til å få en harmonisert forståelse for hva som er god regelverksetterlevelse ved tilsyn av samsvarserklæringer og bakgrunnsdokumentasjon i Norden. 


\section{Annex I. Legislation and guidance: Overview on EU and Nordic webpages etc.}

\section{EU Legislation, FCM}

For food contact materials and articles the general legislation is the following:

- Framework Regulation (EC) No 1935/2004 on materials and articles intended to come into contact with food

- Regulation (EC) No 2023/2006 on Good Manufacturing Practice for materials and articles intended to come in contact with food

Specific measures are found for some types of materials.

\section{Active and intelligent packaging}

- Regulation (EC) No 450/2009 - active and intelligent materials and articles intended to come into contact with food. ${ }^{11}$

\section{Plastics}

- Regulation (EU) No 10/2011 - plastic materials and articles intended to come into contact with food. ${ }^{12}$

- Regulation (EU) No 1183/2012 amending and correcting Regulation (EU) No 10/2011 on plastic materials and articles intended to come in contact with food. ${ }^{13}$

\footnotetext{
11 http://eur-lex.europa.eu/Notice.do?val=495962:cs\&lang=en\&list=496468:cs,495962:cs,\&pos=2\&,page= $1 \& \mathrm{nbl}=2 \&$ pgs $=10$ \&hwords $=$

$12 \mathrm{http}$ ///eur-lex.europa.eu/LexUriServ/LexUriServ.do?uri=CONSLEG:2011R0010:20111230:EN:PDF

${ }^{13} \mathrm{http}: / /$ eur-lex.europa.eu/LexUriServ/LexUriServ.do?uri=CELEX:32012R1183:EN:NOT
} 
- Corrigendum to Regulation (EU) No 1183/2012 amending and correcting Regulation (EU) No 10/2011 on plastic materials and articles intended to come in contact with food. ${ }^{14}$

- Regulation (EU) No 1282/2011 amending and correcting Regulation (EU) No 10/2011 on plastic materials and articles intended to come in contact with food. ${ }^{15}$

- Regulation (EC) No 282/2008 - recycled plastic materials and articles intended to come into contact with foods. ${ }^{16}$

- Regulation (EU) No 284/2011 - import procedures for polyamide and melamine plastic kitchenware from China and Hong Kong. ${ }^{17}$

- Regulation (EU) No 321/2011 - restricting Bisphenol A use in plastic infant feeding bottles. ${ }^{18}$

\section{Other materials}

- Directive (EC) No 1895/2005 - materials and articles made of regenerated cellulose film intended to come into contact with foods. ${ }^{19}$

- Directive 84/500/EEC - approximating EU countries' laws on ceramic articles intended to come into contact with foods. 20

- Regulation (EC) No 1895/2005 - restricting use of certain epoxy derivatives in materials and articles intended to come into contact with food. ${ }^{21}$

- Directive 93/11/EEC - release of N-nitrosamines and N-nitrosatable substances from rubber teats and soothers. ${ }^{22}$

Directives are implemented in national legislation and can be found on the webpages of the national authorities.

For EU documents the different language versions are available on the Commission webpage.

\footnotetext{
14 http://eur-lex.europa.eu/LexUriServ/LexUriServ.do?uri=CELEX:32012R1183R(01):EN:NOT $15 \mathrm{http}: / /$ eur-lex.europa.eu/LexUriServ/LexUriServ.do?uri=CELEX:32011R1282:EN:NOT

16 http://eur-lex.europa.eu/JOHtml.do?uri=0J:L:2008:086:SOM:EN:HTML

$17 \mathrm{http}$ ://eur-lex.europa.eu/LexUriServ/LexUriServ.do?uri=0J:L:2011:077:0025:0029:EN:PDF

${ }^{18} \mathrm{http}$ ://eur-lex.europa.eu/LexUriServ/LexUriServ.do?uri=0J:L:2011:087:0001:0002:EN:PDF

$19 \mathrm{http}$ //eur-lex.europa.eu/LexUriServ/LexUriServ.do?uri=CELEX:32007L0042:EN:NOT

$20 \mathrm{http}: / /$ eur-lex.europa.eu/LexUriServ/LexUriServ.do?uri=CONSLEG:1984L0500:20050520:EN:PDF

$21 \mathrm{http}$ ://eur-lex.europa.eu/LexUriServ/LexUriServ.do?uri=CELEX:32005R1895:EN:NOT

22 http://eur-lex.europa.eu/LexUriServ/LexUriServ.do?uri=CELEX:31993L0011:EN:NOT
} 


\section{Useful webpages, EU and national}

- EU Commission: http://ec.europa.eu/food/food/chemicalsafety/ foodcontact/legisl_list_en.htm

- FCM Database: https://webgate.ec.europa.eu/sanco_foods/main/ ?event=display

\section{Nordic authorities}

- Danish Veterinary and Food Administration: www.fvst.dk

- Faroese Food \& Veterinary Authority: www.hfs.fo (No national legislation on food contact materials).

- Finnish Food Safety Authority: http://www.evira.fi

- The Icelandic Food and Veterinary Authority: www.mast.is (No national legislation on food contact materials).

- Norwegian Food Safety Authority: http://www.mattilsynet.no/

- Swedish National Food Agency: www.livsmedelsverket.se

\section{Other authorities}

- The Irish online guidance of issuing DoCs for different kinds of FCM operators EASY Doc: http://easydoc.fsai.ie/

- German recommendations - BfR: http://www.bfr.bund.de/en/ health_assessment_of_food_contact_materials-528.html

\section{Other EU Legislation with relevance to food contact materials}

\section{EU Food Law}

Regulation (EC) No. 178/2002 of the European Parliament and of the Council of 28th January 2002 on general principles and requirements in the food law, on establishment of the European Food Authority and procedures related to food safety. 


\section{EU Official control}

Regulation (EC) No. 882/2004 of the European Parliament and of the Council of 29 April 2004 on official control performed to ensure the verification of compliance with (feed and) food law, animal health and animal welfare rules.

\section{EU Hygiene}

Regulation (EC) No. 852/2004 of the European Parliament and of the Council of 29 April 2004 on hygiene of foodstuff:

- EU Food additives: http://ec.europa.eu/food/food/fAEF/ additives/index_en.htm

- EU Food flavours: http://ec.europa.eu/food/food/fAEF/ flavouring/index_en.htm

- Database: https://webgate.ec.europa.eu/sanco_foods

\section{Guidance documents, EU, Nordic and others}

Guidance document on the submission of a dossier on a substance to be used in Food Contact Materials for evaluation by EFSA:

- http://www.efsa.europa.eu/en/efsajournal/pub/21r

Union Guidelines on Regulation (EU) No 10/2011 on plastic materials and articles intended to come into contact with food:

- http://ec.europa.eu/food/food/chemicalsafety/foodcontact/docs/10 -2011_plastic_guidance_en.pdf

EU Guidance on information in the plastics supply chain - Guidance on Regulation (EU) No 10/2011 on plastic materials and articles intended to come into contact with food as regards information in the supply chain:

- http://ec.europa.eu/food/food/chemicalsafety/foodcontact/docs/gu idance_reg-10-2011_en.pdf

Food contact materials: Printing inks, Nordic Publication:

- http://dx.doi.org/10.6027/TN2012-521 
Paper and board for food contact, Nordic Publication:

- http://dx.doi.org/10.6027/TN2008-515

Food contact materials - metals and alloys: Nordic guidance for authorities, industry and trade:

- http://dx.doi.org/10.6027/TN2015-522

Guidelines for the application of the regulation (EC) 2023/2006 to the supply chain of materials and articles intended to come into contact with food (Italian guideline, in English):

- http://www.iss.it/binary/publ/cont/11_37_web.pdf 



\section{Annex II. Templates for declaration of compliance}

Template no 1: General requirements for all food contact materials The templates below are meant for use in drafting a declaration of compliance for all types of food contact materials

\begin{tabular}{|c|c|c|c|c|}
\hline & Check point & Content & Example & $\begin{array}{l}\text { Controlled } \\
\text { and in } \\
\text { compliance }\end{array}$ \\
\hline 1.1 & Legislation & $\begin{array}{l}\text { Declaration of compli- } \\
\text { ance with national and } \\
\text { EU legislation on FCM. }\end{array}$ & $\begin{array}{l}\text { Confirmation that the material meets relevant } \\
\text { legislative requirements. Names on relevant } \\
\text { legislation e.g.: } \\
\text { EU regulation } 1935 / 2004 \text {, EU regulation } \\
2023 / 2006 \text {, plastics regulation EU/10/2011 as } \\
\text { amended } \\
\text { Reference to other relevant legislation or } \\
\text { recommendation. E.g. the BfR recommendation } \\
\text { XV on silicones and XXXVI on paper and board. }\end{array}$ & \\
\hline 1.2 & Updating & $\begin{array}{l}\text { The declaration of com- } \\
\text { pliance shall always be } \\
\text { updated. }\end{array}$ & $\begin{array}{l}\text { Updating is performed when there are } \\
\text { changes in the legislation or if changes are } \\
\text { made in the composition or production of the } \\
\text { FCM (including intermediates). } \\
\text { Preferably, the documentation should be } \\
\text { revised periodically e.g. every } 2 \text { nd year. }\end{array}$ & \\
\hline 1.3 & Language & $\begin{array}{l}\text { The in-house declaration } \\
\text { of compliance and } \\
\text { documentation shall be } \\
\text { written in a language } \\
\text { understood by industry } \\
\text { and trade and the public } \\
\text { food inspection. }\end{array}$ & $\begin{array}{l}\text { In Denmark, Norway and Sweden accepted } \\
\text { languages would be the Scandinavian lan- } \\
\text { guages and English. } \\
\text { Finland accepts Finnish, Swedish and English. } \\
\text { Iceland accepts Icelandic, English, Danish, } \\
\text { Norwegian and Swedish. Faroe Islands accepts } \\
\text { Faroese, English and Danish. }\end{array}$ & \\
\hline 1.4 & $\begin{array}{l}\text { Knowledge of } \\
\text { suppliers and } \\
\text { customers }\end{array}$ & $\begin{array}{l}\text { All links in the chain } \\
\text { should have some } \\
\text { knowledge of the legal } \\
\text { frame under which their } \\
\text { suppliers and customers } \\
\text { work. }\end{array}$ & $\begin{array}{l}\text { A dialog between the stakeholders is needed } \\
\text { to support evaluation of compliance with legal } \\
\text { requirements. } \\
\text { Limited knowledge of the supplier and his/her } \\
\text { quality assurance system should be followed } \\
\text { by closer in-house control by the customer. }\end{array}$ & \\
\hline
\end{tabular}




\begin{tabular}{|c|c|c|c|c|}
\hline & Check point & Content & Example & $\begin{array}{l}\text { Controlled } \\
\text { and in } \\
\text { compliance }\end{array}$ \\
\hline 1.5 & $\begin{array}{l}\text { GMP } \\
\text { requirements }\end{array}$ & $\begin{array}{l}\text { Statement and documen- } \\
\text { tation on e.g. quality } \\
\text { assurance and training } \\
\text { see regulation (EC) No } \\
2023 / 2006 \text {. } \\
\text { The critical points should } \\
\text { be addressed in quality } \\
\text { assurance of the produc- } \\
\text { tion process. }\end{array}$ & $\begin{array}{l}\text { Some examples: } \\
\text { X-Company producing Z-material follow the } \\
\text { requirements in EU regulation 2023/2006 in } \\
\text { the production of Y-FCM (name). } \\
\text { When the company follows the Italian guide- } \\
\text { line, a reference to the Italian guidance could } \\
\text { be included, see http://www.iss.it/binary/ } \\
\text { publ/cont/11_37_web.pdf }\end{array}$ & \\
\hline 1.6 & Analysis & $\begin{array}{l}\text { There are two general } \\
\text { points: } \\
\text { Sampling for analysis } \\
\text { shall take place at critical } \\
\text { points, like e.g. start of } \\
\text { production, and after } \\
\text { hardening of adhesives. } \\
\text { Analysis should in } \\
\text { general follow a stand- } \\
\text { ardized method for } \\
\text { which the laboratories } \\
\text { have an accreditation. }\end{array}$ & $\begin{array}{l}\text { Some examples: } \\
\text { "For material Y-FCM samples are taken after } \\
\text { hardening in XX days of the adhesives in the } \\
\text { plastics layers (hardening of some adhesives } \\
\text { in a multilayer material is a critical point)." } \\
\text { "Analysis show migration below SML/GML in } \\
\text { legislation X" } \\
\text { (Critical points in the analysis are mentioned } \\
\text { in Annex IV). }\end{array}$ & \\
\hline 1.7 & $\begin{array}{l}\text { Model calcula- } \\
\text { tions }\end{array}$ & $\begin{array}{l}\text { Model calculations of } \\
\text { migration from plastics } \\
\text { and other FCM shall } \\
\text { follow recognized } \\
\text { methods for calculation }\end{array}$ & $\begin{array}{l}\text { Migration of chemicals from the FCM shall be } \\
\text { calculated on worst case assumptions based } \\
\text { on the recipe. } \\
\text { Migration of chemicals in plastics can be } \\
\text { calculated using software. If modelling is } \\
\text { performed, the software should be specified. }\end{array}$ & \\
\hline 1.8 & $\begin{array}{l}\text { Supporting } \\
\text { documentation } \\
\text { availability }\end{array}$ & $\begin{array}{l}\text { Supporting documenta- } \\
\text { tion (detailed infor- } \\
\text { mation) shall be availa- } \\
\text { ble on the FCM on } \\
\text { request. In general, it } \\
\text { could be kept in each } \\
\text { individual link of the } \\
\text { chain and not necessary } \\
\text { be given to customers. }\end{array}$ & $\begin{array}{l}\text { Supporting documentation (detailed infor- } \\
\text { mation) will be available on request by } \\
\text { authorities within 1-2 weeks. }\end{array}$ & \\
\hline 1.9 & $\begin{array}{l}\text { Sum of } \\
\text { evaluation }\end{array}$ & & & \\
\hline
\end{tabular}




\section{Template no 2: Producers of starting substances: chemicals}

Producers cover the national producers, producers in EU and importers of chemical substances into EU from third countries.

\begin{tabular}{|c|c|c|c|c|}
\hline $\begin{array}{l}\text { Check } \\
\text { point }\end{array}$ & & $\begin{array}{l}\text { Content/Min. requirement } \\
\text { to answer }\end{array}$ & Examples/explanations & $\begin{array}{l}\text { Controlled } \\
\text { and in } \\
\text { compliance }\end{array}$ \\
\hline 2.1 & $\begin{array}{l}\text { Name and address } \\
\text { of the producer of } \\
\text { the chemical } \\
\text { substance(s) or the } \\
\text { business operator }\end{array}$ & $\begin{array}{l}\text { Physical address of the } \\
\text { company } \\
\text { Internet address (if specific } \\
\text { company can be identified } \\
\text { via the internet webpage) } \\
\text { Specific company data }{ }^{23}\end{array}$ & $\begin{array}{l}\text { Text example: } \\
\text { "FCM-company, X-street, Z-city, Y- } \\
\text { country. } \\
\text { Or www.FCM-company.com }\end{array}$ & \\
\hline 2.2 & Traceability $^{24}$ & $\begin{array}{l}\text { Names on suppliers of } \\
\text { chemicals }\end{array}$ & & \\
\hline 2.3 & $\begin{array}{l}\text { Identity of chemical } \\
\text { substance }\end{array}$ & $\begin{array}{l}\text { E.g. name on the chemical } \\
\text { substance, } \\
\text { CAS-number or FCM } \\
\text { substance number. }\end{array}$ & $\begin{array}{l}\text { Text example: } \\
\text { "1,3,5-Triazine-2,4,6-triamine or } \\
\text { melamine CAS no 108-78-1". FCM } \\
\text { nr. } 239\end{array}$ & \\
\hline 2.4 & $\begin{array}{l}\text { Date of issuing the } \\
\text { DoC }\end{array}$ & $\begin{array}{l}\text { Date of issuing the DoC } \\
\text { The DoC should be updated } \\
\text { when the production of the } \\
\text { materials is changed. }\end{array}$ & $\begin{array}{l}\text { DD-MM-YY } \\
\text { If no changes in the production, a } \\
\text { proposal is to update every } 2 \text { nd } \\
\text { year. }\end{array}$ & \\
\hline \multicolumn{5}{|c|}{ Risk assessment/compliance with regulation (EC) No 1935/2004, article 3 a } \\
\hline 2.5 & Specific restrictions & $\begin{array}{l}\text { Reference to specific } \\
\text { regulation }\end{array}$ & $\begin{array}{l}\text { Information on the chemical e.g. } \\
\text { authorized substance, specific } \\
\text { migration limits in the final FCM. }\end{array}$ & \\
\hline 2.6 & $\begin{array}{l}\text { EFSA opinion of the } \\
\text { chemical substances } \\
\text { (if available) }\end{array}$ & Reference to opinion & $\begin{array}{l}\text { Opinion number } \\
\text { Copy of the EFSA report } \\
\text { Information on chemical e.g. TDIs }\end{array}$ & \\
\hline 2.7 & $\begin{array}{l}\text { Producers self- } \\
\text { assessment }\end{array}$ & $\begin{array}{l}\text { Conclusion from risk } \\
\text { assessment } \\
\text { Documentation on toxico- } \\
\text { logical testing in accord- } \\
\text { ance with the EFSA re- } \\
\text { quirements for FCM }\end{array}$ & $\begin{array}{l}\text { Text example: } \\
\text { "Z-chemical is risk assessed and it is } \\
\text { concluded that the chemical can be } \\
\text { used in X-FCM according to EU } \\
\text { regulation } 1935 / 2004 \text {, article } 3 \text { ". } \\
\text { Full risk assessment report following } \\
\text { the EFSA guideline must be available } \\
\text { on request }\end{array}$ & \\
\hline
\end{tabular}

${ }^{23}$ In Denmark companies has a CVR-number and a P-number. In Sweden every company has an organization number. In Finland the companies have an official company code number. In Iceland the companies have ID and VAT numbers. In Norway the companies have an organization number.

24 Traceability is mentioned as a check point in the templates for drafting a declaration of compliance. This is to remind both business operators and the control authorities that business operators must document traceability in the supply chain. However, this can be done independently of the declaration of compliance, e.g. in a separate document. 


\begin{tabular}{|c|c|c|c|c|}
\hline $\begin{array}{l}\text { Check } \\
\text { point }\end{array}$ & & $\begin{array}{l}\text { Content/Min. requirement } \\
\text { to answer }\end{array}$ & Examples/explanations & $\begin{array}{l}\text { Controlled } \\
\text { and in } \\
\text { compliance }\end{array}$ \\
\hline 2.8 & $\begin{array}{l}\text { Risk assessment of } \\
\text { compliance from } \\
\text { other countries } \\
\text { following guide- } \\
\text { lines and data } \\
\text { requirements } \\
\text { equivalent to the } \\
\text { EFSA requirements, } \\
\text { like BfR or FDA. }\end{array}$ & $\begin{array}{l}\text { Conclusion from risk } \\
\text { assessment } \\
\text { Reference to FDA, BfR, } \\
\text { other legislation or recom- } \\
\text { mendation covering the } \\
\text { substance and its use in } \\
\text { specific FCM }\end{array}$ & $\begin{array}{l}\text { Text example: } \\
\text { "Z-chemicals are approved to be } \\
\text { used in X-FCM according to specific } \\
\text { reference in FDA, BfR etc." }\end{array}$ & \\
\hline \multicolumn{5}{|c|}{ Other check points } \\
\hline 2.9 & $\begin{array}{l}\text { Dual use additives, } \\
\text { e.g. if the chemicals } \\
\text { are regulated as } \\
\text { food additives, } \\
\text { including the } \\
\text { requirements for } \\
\text { purity and identity }\end{array}$ & $\begin{array}{l}\text { Specific information on } \\
\text { restrictions in other parts of } \\
\text { the legislation, e.g. the food } \\
\text { additives or flavouring } \\
\text { legislation } \\
\text { Relevant legal acts should } \\
\text { be available at this stage }\end{array}$ & $\begin{array}{l}\text { Text example: } \\
\text { "Z-chemical and E-number } X \text { or } \\
\text { FL number } Y \text { is covered by } \\
\text { legislation on food additives or } \\
\text { flavourings, and the require- } \\
\text { ments for purity are fulfilled." }\end{array}$ & \\
\hline 2.10 & $\begin{array}{l}\text { Instructions of use, } \\
\text { if needed }\end{array}$ & $\begin{array}{l}\text { Limitations in use (process } \\
\text { conditions, reaction time, } \\
\text { temperature etc.) }\end{array}$ & & \\
\hline & Sum of evaluation & & & \\
\hline
\end{tabular}




\section{Template no 3: Producers of starting materials: raw materials of natural origin like natural rubber and wooden fibres}

\begin{tabular}{|c|c|c|c|c|}
\hline & Check point & $\begin{array}{l}\text { Content/Min. requirement to } \\
\text { answer }\end{array}$ & Examples/explanations & $\begin{array}{l}\text { Controlled } \\
\text { and in } \\
\text { compliance }\end{array}$ \\
\hline 3.1 & $\begin{array}{l}\text { Name and address of } \\
\text { the producer of the } \\
\text { starting material or } \\
\text { the business operator }\end{array}$ & $\begin{array}{l}\text { Physical address of the company } \\
\text { Internet address (if specific com- } \\
\text { pany can be identified via the } \\
\text { internet site) } \\
\text { Specific company data }\end{array}$ & $\begin{array}{l}\text { Text example: } \\
\text { "FCM-company, X-street, Z-city, } \\
\text { Y-country". } \\
\text { Or www.FCM-company.com }\end{array}$ & \\
\hline 3.2 & Traceability $^{26}$ & $\begin{array}{l}\text { Names of suppliers of raw materials } \\
\text { (not traceability to a specific geo- } \\
\text { graphical area) }\end{array}$ & $\begin{array}{l}\text { Text example: } \\
\text { "Wood supplied by FCM- } \\
\text { company, X-street, Z-city, Y- } \\
\text { country." }\end{array}$ & \\
\hline 3.3 & $\begin{array}{l}\text { Generic name e.g. } \\
\text { fibers of wood } \\
\text { (species) }\end{array}$ & $\begin{array}{l}\text { Information on raw materials like } \\
\text { fibers from e.g. grass or other } \\
\text { sources } \\
\text { Wooden fibers, see Nordic report on } \\
\text { paper and board }\end{array}$ & $\begin{array}{l}\text { Text example: } \\
\text { "Wooden fibers from Pine" }\end{array}$ & \\
\hline 3.4 & $\begin{array}{l}\text { Date of issuing the } \\
\text { DoC }\end{array}$ & $\begin{array}{l}\text { Date of issuing the DoC } \\
\text { The DoC should be updated when } \\
\text { production of the materials is } \\
\text { changed. }\end{array}$ & $\begin{array}{l}\text { DD-MM-YY } \\
\text { If no changes in the production, a } \\
\text { proposal is to update every } 2 \text { nd } \\
\text { year. }\end{array}$ & \\
\hline \multicolumn{5}{|c|}{ Risk assessment/compliance with regulation (EC) No 1935/2004, article 3 a } \\
\hline 3.5 & $\begin{array}{l}\text { EFSA opinion of the } \\
\text { natural component } \\
\text { (if available) }\end{array}$ & $\begin{array}{l}\text { Reference to opinion } \\
\text { Copy of the EFSA report }\end{array}$ & Opinion number & \\
\hline 3.6 & $\begin{array}{l}\text { Producer self- } \\
\text { assessment }\end{array}$ & $\begin{array}{l}\text { Conclusion from risk assessment } \\
\text { Documentation on toxicological } \\
\text { testing in accordance with the EFSA } \\
\text { requirements for FCM }\end{array}$ & $\begin{array}{l}\text { Text example: } \\
\text { "Z-fibres is risk assessed and it is } \\
\text { concluded that the fibres can be } \\
\text { used in X-FCM according to EU } \\
\text { regulation } 1935 / 2004 \text {, article } 3 . " \\
\text { Full risk assessment report follow- } \\
\text { ing the EFSA guideline available on } \\
\text { request. }\end{array}$ & \\
\hline
\end{tabular}

25 In Denmark companies has a CVR-number and a P-number. In Sweden every company has an organization number. In Finland the companies have an official company code number. In Iceland the companies have ID and VAT numbers. In Norway the companies have an organization number.

${ }^{26}$ Traceability is mentioned as a check point in the templates for drafting a declaration of compliance. This is to remind both business operators and the control authorities that business operators must document traceability in the supply chain. However, this can be done independently of the declaration of compliance, e.g. in a separate document. 


\begin{tabular}{|c|c|c|c|c|}
\hline & Check point & $\begin{array}{l}\text { Content/Min. requirement to } \\
\text { answer }\end{array}$ & Examples/explanations & $\begin{array}{l}\text { Controlled } \\
\text { and in } \\
\text { compliance }\end{array}$ \\
\hline 3.7 & $\begin{array}{l}\text { Risk assessment of } \\
\text { compliance from other } \\
\text { countries following } \\
\text { guidelines and data } \\
\text { requirements equivalent } \\
\text { to the EFSA require- } \\
\text { ments, like BfR or FDA. }\end{array}$ & $\begin{array}{l}\text { Conclusion from risk assessment } \\
\text { Reference to FDA, BfR, other } \\
\text { legislation or recommendation } \\
\text { covering the fibres and their use in } \\
\text { specific FCM }\end{array}$ & $\begin{array}{l}\text { Text example: } \\
\text { "Z-fibres are approved to be used } \\
\text { in X-FCM according to (specific } \\
\text { reference in FDA, BfR etc.)" }\end{array}$ & \\
\hline \multicolumn{5}{|c|}{ Other check points } \\
\hline 3.8 & $\begin{array}{l}\text { Dual use additives, } \\
\text { e.g. if the chemicals } \\
\text { are regulated as food } \\
\text { additives, including } \\
\text { the requirements for } \\
\text { identity }\end{array}$ & $\begin{array}{l}\text { Specific information on restrictions in } \\
\text { other parts of the legislation, e.g. food } \\
\text { additives or flavouring legislation } \\
\text { Relevant legal acts should be availa- } \\
\text { ble at this stage }\end{array}$ & $\begin{array}{l}\text { Text example: } \\
\text { "Z-fibers, or components in them } \\
\text { (E-number or FL number) are } \\
\text { covered by legislation on food } \\
\text { additives or flavourings." }\end{array}$ & \\
\hline 3.9 & $\begin{array}{l}\text { Instructions of use, if } \\
\text { needed }\end{array}$ & $\begin{array}{l}\text { Limitations in use (process condi- } \\
\text { tions, reaction time, temperature } \\
\text { etc.) }\end{array}$ & $\begin{array}{l}\text { Text example: } \\
\text { "Should not be used in acidic } \\
\text { medium" }\end{array}$ & \\
\hline & Sum of evaluation & & & \\
\hline
\end{tabular}


Template no 4: Producers of Intermediates like e.g. formulations of printing inks, surface coatings, lacquers, polymers or master batches Producers cover the national producers, producers in EU and importers of intermediates into EU from third countries.

\begin{tabular}{|c|c|c|c|c|}
\hline & Check point & Content/Min. requirement to answer & Examples/explanations & $\begin{array}{l}\text { Controlled } \\
\text { and in } \\
\text { compliance }\end{array}$ \\
\hline 4.1 & $\begin{array}{l}\text { Name and } \\
\text { address of the } \\
\text { producer of the } \\
\text { intermediate or } \\
\text { the business } \\
\text { operator }\end{array}$ & $\begin{array}{l}\text { Physical address of the company } \\
\text { Internet address (if specific company } \\
\text { can be identified via the internet } \\
\text { webpage) } \\
\text { Specific company data }{ }^{27}\end{array}$ & $\begin{array}{l}\text { Text example: } \\
\text { "A-lacquer-company, X-street, Z- } \\
\text { city, Y-country". } \\
\text { Or www.A-lacquer-company.com }\end{array}$ & \\
\hline 4.2 & Traceability $^{28}$ & Names of suppliers of chemicals & & \\
\hline 4.3 & $\begin{array}{l}\text { Identity of the } \\
\text { materials from } \\
\text { intermediate } \\
\text { stages of manu- } \\
\text { facture }\end{array}$ & $\begin{array}{l}\text { Trade name } \\
\text { Identification code for the production }\end{array}$ & $\begin{array}{l}\text { Text example: } \\
\text { "X-Lacquer-SUPER } \\
\text { Production code date/code" }\end{array}$ & \\
\hline 4.4 & $\begin{array}{l}\text { Date of issuing } \\
\text { the DoC }\end{array}$ & $\begin{array}{l}\text { Date of issuing the DoC } \\
\text { The DoC should be updated when the } \\
\text { production of the materials is changed. }\end{array}$ & $\begin{array}{l}\text { DD-MM-YY } \\
\text { If no changes in the production, a } \\
\text { proposal is to update every } 2 \text { nd } \\
\text { year. }\end{array}$ & \\
\hline
\end{tabular}

\begin{tabular}{|c|c|c|c|}
\hline 4.5 & $\begin{array}{l}\text { Specific } \\
\text { restrictions }\end{array}$ & $\begin{array}{l}\text { Reference to specific regulation on } \\
\text { chemicals e.g. monomers and additives } \\
\text { on positive lists in the legislation }\end{array}$ & $\begin{array}{l}\text { Information on chemicals e.g. } \\
\text { authorized substances, specific } \\
\text { migration limits from the final } \\
\text { FCM. } \\
\text { When positive lists: Chemicals } \\
\text { can legally be used according to } \\
\text { the plastics regulation } \\
\text { EU/10/2011, Annex I. }\end{array}$ \\
\hline 4.6 & $\begin{array}{l}\text { EFSA assessment, } \\
\text { including report } \\
\text { no. (if available) }\end{array}$ & $\begin{array}{l}\text { None-regulated substance }{ }^{29} \text { Reference } \\
\text { to the EFSA report } \\
\text { Risk assessment should include the } \\
\text { intended use. }\end{array}$ & $\begin{array}{l}\text { For none-regulated substances: } \\
\text { opinion number. } \\
\text { Information on components, e.g. } \\
\text { TDIs. }\end{array}$ \\
\hline
\end{tabular}

${ }^{27}$ In Denmark companies has a CVR-number and a P-number. In Sweden every company has an organization number. In Finland the companies have an official company code number. In Iceland the companies have ID and VAT numbers. In Norway the companies have an organization number.

${ }^{28}$ Traceability is mentioned as a check point in the templates for drafting a declaration of compliance. This is to remind both business operators and the control authorities that business operators must document traceability in the supply chain. However, this can be done independently of the declaration of compliance, e.g. in a separate document.

29 "None-regulated substances" are used for substances not covered by positive lists in the legislation, but only by the general requirements in regulation 1935/2004. 


\begin{tabular}{|c|c|c|c|c|}
\hline & Check point & Content/Min. requirement to answer & Examples/explanations & $\begin{array}{l}\text { Controlled } \\
\text { and in } \\
\text { compliance }\end{array}$ \\
\hline 4.7 & $\begin{array}{l}\text { Producer self- } \\
\text { assessment }\end{array}$ & $\begin{array}{l}\text { Conclusion from risk assessment } \\
\text { Documentation on toxicological testing } \\
\text { in accordance with the EFSA require- } \\
\text { ments for FCM }\end{array}$ & $\begin{array}{l}\text { Text example: } \\
\text { "Z-chemicals is risk assessed and } \\
\text { it is concluded that the chemical } \\
\text { can be used in X-FCM according } \\
\text { to EU regulation } 1935 / 2004, \\
\text { article } 3 . " \\
\text { Full risk assessment report } \\
\text { following the EFSA guideline } \\
\text { available on request }\end{array}$ & \\
\hline 4.8 & $\begin{array}{l}\text { Risk assessment } \\
\text { of compliance } \\
\text { from other } \\
\text { countries follow- } \\
\text { ing guidelines and } \\
\text { data require- } \\
\text { ments equivalent } \\
\text { to the EFSA } \\
\text { requirements, } \\
\text { like BfR or FDA. }\end{array}$ & $\begin{array}{l}\text { Conclusion from risk assessment } \\
\text { Reference to FDA, BfR, other legislation } \\
\text { or recommendation covering the } \\
\text { substance and its use in specific FCM }\end{array}$ & $\begin{array}{l}\text { Text example: } \\
\text { "Z-chemicals are approved to be } \\
\text { used in X-FCM according to } \\
\text { (specific reference in FDA, BfR } \\
\text { etc.)" }\end{array}$ & \\
\hline \multicolumn{5}{|c|}{ Other check points } \\
\hline 4.9 & $\begin{array}{l}\text { Adequate infor- } \\
\text { mation about non } \\
\text { intentionally } \\
\text { added substances } \\
\text { (NIAS) e.g. } \\
\text { products of } \\
\text { degradation }\end{array}$ & $\begin{array}{l}\text { The producer shall have knowledge of } \\
\text { the presence of these substances. If it } \\
\text { can be documented that these sub- } \\
\text { stances do not migrate, this is suffi- } \\
\text { cient. } \\
\text { If these substances are migrating the } \\
\text { following information shall be availa- } \\
\text { ble: } \\
\text { Covered by national legislation } \\
\text { Identity of the chemicals, FCM- } \\
\text { substance no, ref-number, CAS-number } \\
\text { or chemical names } \\
\text { Restrictions, if any. }\end{array}$ & $\begin{array}{l}\text { Text example: } \\
\text { "FCM-X is composed of chemi- } \\
\text { cals, including degradation or } \\
\text { reaction products either on the } \\
\text { positive list for plastics in the } \\
\text { plastics regulation EU/10/2011, } \\
\text { Annex I, FCM number or assessed } \\
\text { and found in compliance with } \\
\text { regulation } 1935 / 2004 \text {, article } 3 . "\end{array}$ & \\
\hline 4.10 & $\begin{array}{l}\text { Dual use additives, } \\
\text { e.g. if the chemi- } \\
\text { cals are regulated } \\
\text { as food additives, } \\
\text { including the } \\
\text { requirements for } \\
\text { identity. }\end{array}$ & $\begin{array}{l}\text { Some chemicals e.g. benzoic acid and } \\
\text { BHT are used in FCM and covered by } \\
\text { the plastic regulation. } \\
\text { Specific information on restrictions in } \\
\text { other parts of the legislation, e.g. the } \\
\text { food additives- or flavouring legislation } \\
\text { Relevant legal acts from these areas } \\
\text { should be available at this stage. }\end{array}$ & $\begin{array}{l}\text { Text example: } \\
\text { "X-FCM contains benzoic acid E nr } \\
210 " \\
\text { or } \\
\text { "X-FCM contains flavouring } \\
\text { substance FL-no" }{ }^{30}\end{array}$ & \\
\hline
\end{tabular}

${ }^{30} \mathrm{FL}-$ number is the number of flavouring substances in Commission Implementing Regulation (EU) No 872/2012 of 1st October 2012 adopting the list of flavouring substances provided for by Regulation (EC) No 2232/96 of the European Parliament and of the Council, introducing it in Annex I to Regulation (EC) No 1334/2008 of the European Parliament and of the Council and repealing Commission Regulation (EC) No 1565/2000 and Commission Decision 1999/217/EC. 


\begin{tabular}{|c|c|c|c|c|}
\hline & Check point & Content/Min. requirement to answer & Examples/explanations & $\begin{array}{l}\text { Controlled } \\
\text { and in } \\
\text { compliance }\end{array}$ \\
\hline 4.11 & $\begin{array}{l}\text { Information on } \\
\text { quantitative } \\
\text { content of } \\
\text { substances } \\
\text { functioning as } \\
\text { surface active } \\
\text { biocide. }\end{array}$ & $\begin{array}{l}\text { Biocides used in FCM shall comply with } \\
\text { the biocidal product regulation } \\
528 / 2012 \text {, regulation } 1935 / 2004 \text { and } \\
\text { any national regulations. }{ }^{31}\end{array}$ & & \\
\hline 4.12 & $\begin{array}{l}\text { If needed, advice } \\
\text { on restrictions in } \\
\text { use of the final } \\
\text { FCM. }\end{array}$ & & & \\
\hline & Sum of evaluation & & & \\
\hline
\end{tabular}

31 The requirements for the $\mathrm{DoC}$ will depend on how the biocide regulation is implemented in the FCM legislation 


\section{Template no 5: Producers: Final food contact materials and articles}

Producers cover the national producers, producers in EU and importers of FCM into EU from third countries.

\begin{tabular}{|c|c|c|c|c|}
\hline & Check point & $\begin{array}{l}\text { Content/Min. requirement to } \\
\text { answer }\end{array}$ & Examples/explanations & $\begin{array}{l}\text { Controlled } \\
\text { and in } \\
\text { compliance }\end{array}$ \\
\hline 5.1 & $\begin{array}{l}\text { Name and address } \\
\text { of the producer of } \\
\text { the FCM or the } \\
\text { business operator }\end{array}$ & $\begin{array}{l}\text { Physical address on the responsi- } \\
\text { ble company in the country, e.g. } \\
\text { Iceland } \\
\text { Internet address: If the physical } \\
\text { location can be clearly identified } \\
\text { here. } \\
\text { If an importer gets the DoC from } \\
\text { his or her supplier, they can - as a } \\
\text { minimum - add their name etc. on } \\
\text { the DoC before selling the FCM. }\end{array}$ & $\begin{array}{l}\text { Text example: } \\
\text { "FCM-company, X-street, Z-city, Y- } \\
\text { country." } \\
\text { Or "www.FCM-company.com, } \\
\text { Internet address and identification: e.g. } \\
\text { Denmark CVR-number, Sweden or } \\
\text { Norway Organization number, Finland } \\
\text { official company code number or Iceland } \\
\text { ID and VAT number." }\end{array}$ & \\
\hline 5.2 & Traceability $^{32}$ & $\begin{array}{l}\text { Name and physical address of } \\
\text { supplier of raw materials. } \\
\text { Should not be part of the DoC. }\end{array}$ & $\begin{array}{l}\text { Text example: } \\
\text { "A-FCM-company, X-street, Z-city, Y- } \\
\text { country." } \\
\text { "Or www.A-FCM-company.com" }\end{array}$ & \\
\hline 5.3 & $\begin{array}{l}\text { Identity of the } \\
\text { materials or } \\
\text { articles }\end{array}$ & $\begin{array}{l}\text { Trade name and } \\
\text { type of material(s) } \\
\text { This information is important so } \\
\text { that the DoC can be linked to the } \\
\text { product which it applies to. }\end{array}$ & $\begin{array}{l}\text { Text example: } \\
\text { "Cling film type XYZ" } \\
\text { "Paper, virgin fibers, PET plastics, type of } \\
\text { different layers of a multilayer material } \\
\text { like adhesives, printing inks, metal etc. }\end{array}$ & \\
\hline 5.4 & $\begin{array}{l}\text { Date of issuing the } \\
\text { DoC }\end{array}$ & $\begin{array}{l}\text { Date of issuing the DoC } \\
\text { The DoC should be updated when } \\
\text { something in the production } \\
\text { changes that has an influence on } \\
\text { the properties or composition of } \\
\text { the materials or when changes } \\
\text { relevant for the product are } \\
\text { implemented in the legislation. }\end{array}$ & $\begin{array}{l}\text { DD-MM-YY } \\
\text { If no changes in the production or the } \\
\text { legislation, it is recommended to update } \\
\text { every } 2 \text { nd year. } \\
\text { It should be taken into account that } \\
\text { some FCM have a long shelf life and a } \\
\text { slow turnover, e.g. process equipment. }\end{array}$ & \\
\hline
\end{tabular}

32 Traceability is mentioned as a check point in the templates for drafting a declaration of compliance. This is to remind both business operators and the control authorities that business operators must document traceability in the supply chain. However, this can be done independently of the declaration of compliance, e.g. in a separate document. 


\begin{tabular}{|c|c|c|c|c|}
\hline & Check point & $\begin{array}{l}\text { Content/Min. requirement to } \\
\text { answer }\end{array}$ & Examples/explanations & $\begin{array}{l}\text { Controlled } \\
\text { and in } \\
\text { compliance }\end{array}$ \\
\hline \multicolumn{5}{|c|}{$\begin{array}{l}\text { Compliance with regulation (EC) No 1935/2004 and specific measures for groups of materials and articles e.g. for plastics } \\
\text { and ceramics }\end{array}$} \\
\hline 5.5 & Specific restrictions & $\begin{array}{l}\text { Reference to specific regulation } \\
\text { on chemicals e.g. monomers } \\
\text { and additives on positive lists in } \\
\text { the legislation. }\end{array}$ & $\begin{array}{l}\text { Information on chemicals e.g. authorized } \\
\text { substances, specific migration limits from } \\
\text { the final FCM. } \\
\text { When positive lists: } \\
\text { Text example (for plastics): } \\
\text { "Chemicals can legally be used according } \\
\text { to the plastics regulation EU/10/2011, } \\
\text { Annex I." } \\
\text { For substances on the Union list in the } \\
\text { Plastic Regulation: The identity of the } \\
\text { used substances can be identified, but it } \\
\text { is not mandatory. In the plastic regula- } \\
\text { tion, annex IV the wording "adequate } \\
\text { information" is used. As a minimum it } \\
\text { should be stated that these substances } \\
\text { are on the Union list and are not migrat- } \\
\text { ing above the migration limits if the } \\
\text { material is used according to given } \\
\text { restrictions for use. }\end{array}$ & \\
\hline 5.6 & $\begin{array}{l}\text { EFSA assessment, } \\
\text { including report no. } \\
\text { (if available) }\end{array}$ & $\begin{array}{l}\text { None-regulated substance. }{ }^{33} \\
\text { Reference to EFSA report } \\
\text { Risk assessment should include } \\
\text { the intended use. }\end{array}$ & $\begin{array}{l}\text { For none-regulated substances: EFSA } \\
\text { opinion number } \\
\text { Information on components, e.g. TDIs } \\
\text { All substances should ideally be identi- } \\
\text { fied, but it is not mandatory. The mini- } \\
\text { mum requirement is a statement that all } \\
\text { substances are risk assessed according to } \\
\text { Regulation } 1935 / 2004 \text {, article } 3 \text {. }\end{array}$ & \\
\hline 5.7 & $\begin{array}{l}\text { Producer self- } \\
\text { assessment }\end{array}$ & $\begin{array}{l}\text { Conclusion from risk assessment } \\
\text { Documentation on toxicological } \\
\text { testing in accordance with the } \\
\text { EFSA requirements for FCM. }\end{array}$ & $\begin{array}{l}\text { Text example: } \\
\text { "Z-chemicals is risk assessed and it is } \\
\text { concluded that the chemical can be used } \\
\text { in X-FCM according to EU regulation } \\
1935 / 2004 \text {, article } 3 . " \\
\text { All substances should ideally be identi- } \\
\text { fied, but it is not mandatory. The mini- } \\
\text { mum requirement is a statement that all } \\
\text { substances are risk assessed according to } \\
\text { regulation } 1935 / 2004 \text {, article } 3 \text {. } \\
\text { Full risk assessment report following the } \\
\text { EFSA guideline available on request. }\end{array}$ & \\
\hline
\end{tabular}

33 "None-regulated substances" are used for substances not covered by positive list in legislation, but only by the general requirements in regulation 1935/2004. 


\begin{tabular}{|c|c|c|c|c|}
\hline & Check point & $\begin{array}{l}\text { Content/Min. requirement to } \\
\text { answer }\end{array}$ & Examples/explanations & $\begin{array}{l}\text { Controlled } \\
\text { and in } \\
\text { compliance }\end{array}$ \\
\hline 5.8 & $\begin{array}{l}\text { Risk assessment of } \\
\text { compliance from } \\
\text { other countries } \\
\text { following guide- } \\
\text { lines and data } \\
\text { requirements } \\
\text { equivalent to the } \\
\text { EFSA requirements, } \\
\text { like BfR or FDA. }\end{array}$ & Conclusion from risk assessment & $\begin{array}{l}\text { Risk assessment of compliance from } \\
\text { other countries following guidelines and } \\
\text { data requirements equivalent to the } \\
\text { EFSA requirements, e.g. BfR or FDA. } \\
\text { All substances should ideally be identi- } \\
\text { fied, but it is not mandatory. The mini- } \\
\text { mum requirement is a statement that all } \\
\text { substances are risk assessed according to } \\
\text { regulation } 1935 / 2004 \text {, article } 3 \text {. }\end{array}$ & \\
\hline \multicolumn{5}{|c|}{ Other check points } \\
\hline 5.9 & $\begin{array}{l}\text { Migration of } \\
\text { chemicals, includ- } \\
\text { ing reaction and } \\
\text { degradation } \\
\text { products }\end{array}$ & $\begin{array}{l}\text { Information on analysis of } \\
\text { migration, including specific test } \\
\text { conditions, simulants used or } \\
\text { analysis in foods, duration of } \\
\text { the test etc. } \\
\text { When there is no specific } \\
\text { requirement for testing in the } \\
\text { EU legislation, national legisla- } \\
\text { tion or recommendation, e.g. } \\
\text { from the BfR, could be used as } \\
\text { guidance. } \\
\text { Methods used shall be validated } \\
\text { and limits of detection and } \\
\text { quantification shall take migra- } \\
\text { tion levels into account. } \\
\text { This information could be given } \\
\text { in the supporting documenta- } \\
\text { tion, and not necessarily in the } \\
\text { DoC. }\end{array}$ & $\begin{array}{l}\text { Test conditions should take into account } \\
\text { instructions of use, food types in contact, } \\
\text { temperatures, contact time etc. } \\
\text { If model calculations are used, infor- } \\
\text { mation on the mathematical calculations } \\
\text { should be given. }\end{array}$ & \\
\hline 5.10 & $\begin{array}{l}\text { Adequate infor- } \\
\text { mation about non } \\
\text { intentionally added } \\
\text { substances (NIAS) } \\
\text { e.g. products of } \\
\text { degradation }\end{array}$ & $\begin{array}{l}\text { The producer shall have } \\
\text { knowledge on presence of these } \\
\text { substances. If it can be docu- } \\
\text { mented that these substances } \\
\text { do not migrate, this is sufficient. } \\
\text { If these substances are migrat- } \\
\text { ing the following information } \\
\text { shall be available in the support- } \\
\text { ing documentation: } \\
\text { Covered by national legislation } \\
\text { Identity of the chemicals, FCM- } \\
\text { substance no, ref-number, CAS- } \\
\text { number or chemical names } \\
\text { Restrictions, if any. }\end{array}$ & $\begin{array}{l}\text { Text example: } \\
\text { "FCM-X is composed of chemicals, } \\
\text { including degradation or reaction prod- } \\
\text { ucts either on the positive list for plastics } \\
\text { in the plastics regulation EU/10/2011, } \\
\text { Annex I, FCM number or assessed and } \\
\text { found in compliance with regulation } \\
1935 / 2004 \text {, article 3." }\end{array}$ & \\
\hline 5.11 & $\begin{array}{l}\text { Dual use additives. } \\
\text { Restrictions in } \\
\text { other legislation, } \\
\text { e.g. if the chemi- } \\
\text { cals are regulated } \\
\text { as food additives, } \\
\text { including the } \\
\text { requirements for } \\
\text { identity. }\end{array}$ & $\begin{array}{l}\text { Specification of identity and } \\
\text { content of dual use additives in } \\
\text { the FCM. } \\
\text { E-number or FL number. }\end{array}$ & $\begin{array}{l}\text { Chemicals like benzoic acid and BHT are } \\
\text { used in FCM and covered by the plastic } \\
\text { regulation. } \\
\text { Specific information on restrictions in } \\
\text { other parts of the legislation, e.g. the } \\
\text { food additives legislation can be added, } \\
\text { but this is not mandatory. } \\
\text { The identity of dual-use additives is } \\
\text { important information to the food } \\
\text { establishments and information on } \\
\text { migration or residual content in the } \\
\text { material must be made available to the } \\
\text { customer on request. }\end{array}$ & \\
\hline
\end{tabular}




\begin{tabular}{|c|c|c|c|c|}
\hline & Check point & $\begin{array}{l}\text { Content/Min. requirement to } \\
\text { answer }\end{array}$ & Examples/explanations & $\begin{array}{l}\text { Controlled } \\
\text { and in } \\
\text { compliance }\end{array}$ \\
\hline 5.12 & $\begin{array}{l}\text { Specifications on } \\
\text { the use of the } \\
\text { material or article }\end{array}$ & $\begin{array}{l}\text { (i) type or types of food with } \\
\text { which it is intended to be put in } \\
\text { contact; } \\
\text { (ii) time and temperature of } \\
\text { treatment and storage in } \\
\text { contact with the food; } \\
\text { (iii) ratio of food contact surface } \\
\text { area to volume used to establish } \\
\text { the compliance of the material } \\
\text { or article. }\end{array}$ & $\begin{array}{l}\text { Information necessary for correct use } \\
\text { shall be mentioned. } \\
\text { Text example: } \\
\text { "Plastic lunch box. For the use in contact } \\
\text { with all types of food at temperatures } \\
\text { between }-10{ }^{\circ} \mathrm{C} \text { and }+60^{\circ} \mathrm{C} . \text { " } \\
\text { "Not for fatty or acidic food" } \\
\text { "Can or cannot be used in microwaves" } \\
\text { "Can be used for temperatures from } 0- \\
70 \text { degrees C" } \\
\text { "Glass- and fork symbol". When this } \\
\text { symbol is used without mentioning any } \\
\text { restrictions it means "can be used for all } \\
\text { types of food and all types of process } \\
\text { conditions" (under normal and foreseea- } \\
\text { ble conditions of use). }\end{array}$ & \\
\hline 5.13 & Functional barrier & $\begin{array}{l}\text { When a functional barrier is } \\
\text { used, confirm that non- } \\
\text { evaluated chemicals in layers on } \\
\text { the outer side of the barrier do } \\
\text { not migrate in quantities higher } \\
\text { that } 0.01 \mathrm{mg} / \mathrm{kg} \text { and that they } \\
\text { are not carcinogenic, mutagenic } \\
\text { or toxic to reproduction. }\end{array}$ & $\begin{array}{l}\text { Text example: } \\
\text { "No functional barrier is used" } \\
\text { "The material has a functional barrier } \\
\text { and migration from the outer layers is } \\
\text { tested and in compliance with the } \\
\text { requirements in the plastics regulation } \\
\text { (regulation EU/10/2011, article 13)." } \\
\text { "Aluminium is used as a functional } \\
\text { barrier" }\end{array}$ & \\
\hline 5.14 & $\begin{array}{l}\text { Information on } \\
\text { quantitative } \\
\text { content of sub- } \\
\text { stances functioning } \\
\text { as surface active } \\
\text { biocide }\end{array}$ & $\begin{array}{l}\text { Biocides used in FCM shall } \\
\text { comply with the biocidal prod- } \\
\text { uct regulation } 528 / 2012 \text {, } \\
\text { regulation } 1935 / 2004 \text { and any } \\
\text { national legislation }{ }^{34}\end{array}$ & & \\
\hline 5.15 & $\begin{array}{l}\text { Active or intelligent } \\
\text { components of } \\
\text { packaging material }\end{array}$ & $\begin{array}{l}\text { For active or intelligent compo- } \\
\text { nents, information on maximum } \\
\text { (intended) migration, efficacy } \\
\text { and instructions of use shall be } \\
\text { requested. } \\
\text { Name and quantity of the } \\
\text { substances released by the } \\
\text { active component } \\
\text { Specific purity criteria } \\
\text { Adequate information on the } \\
\text { suitability and effectiveness of } \\
\text { the active or intelligent FCM } \\
\text { See also regulation } 450 / 2009 \\
\text { appendix II. }\end{array}$ & $\begin{array}{l}\text { Text example: } \\
\text { "Active component X-food additive, E- } \\
\text { number" } \\
\text { "Active component Y-flavouring, FL- } \\
\text { number" } \\
\text { "Specific migration into foods minimum } \\
\mathrm{Z} \mathrm{mg/kg,} \mathrm{maximum} \mathrm{W} \mathrm{mg} / \mathrm{kg} \text { " }\end{array}$ & \\
\hline
\end{tabular}

34 The requirements for the DoC will depend on how the biocides regulation will be implemented in the FCM legislation. 


\section{Template no 6: Food producers and importers of pre-packed food}

Food producers cover the national producers, producers in EU and importers of pre-packed food into EU from third countries. This includes retailers with production of food. The FCM of pre-packed food shall comply with the EU legislation. See chapters 7.5 and 7.6.

These business operators are not legally obliged to issue a DoC. However the food producer must have a DoC from their supplier according to the requirements in template no. 1 and template no. 5 . 


\section{Annex III. Supporting documentation in practice}

The supporting documentation is sometimes regarded as confidential information and is not sent along in the supply chain.

This documentation shall be given to authorities on request. The guidance timeframe is that this documentation should be made available for authorities within 1-2 weeks.

When requesting supporting documentation it should be specified whether this documentation is requested for all check points in the declaration of compliance, or for some points, e.g. information on migration and analysis.

Supporting documentation to the different check points is listed below. Supporting documentation for the analytical test results are listed separately in Annex IV.

The list is not exhaustive and supplementary requests could be needed.

\begin{tabular}{|c|c|c|}
\hline Check point & Supporting documentation & Requested \\
\hline $\begin{array}{l}\text { 1. Identity and address of the business operator issuing } \\
\text { the declaration of compliance. }\end{array}$ & - & \\
\hline $\begin{array}{l}\text { 2. Identity and address of the business operator which } \\
\text { manufactures or imports the food contact material or } \\
\text { products from intermediate stages of their manufactur- } \\
\text { ing or the substances intended for the manufacturing of } \\
\text { those materials and articles. }\end{array}$ & - & \\
\hline $\begin{array}{l}\text { 3. Identity of the materials, the articles, products from } \\
\text { intermediate stages of manufacture or the substances } \\
\text { intended for the manufacturing of those materials and } \\
\text { articles. }\end{array}$ & $\begin{array}{l}\text { Connection shall be clearly demonstrated be- } \\
\text { tween the FCM product, trade name and inter- } \\
\text { mediates used in the production. } \\
\text { Specific information on the materials used like } \\
\text { e.g. plastics, adhesives and lacquers. }\end{array}$ & \\
\hline
\end{tabular}




$\begin{array}{lll}\text { Check point } & \text { Supporting documentation } & \text { Requested }\end{array}$

4. Date of the declaration ${ }^{35}$

5. Confirmation that the FCM, products from intermediate stages of manufacture or the substances and processes meet relevant requirements laid down in regulation (EC) No 1935/2004 and (EC) No 2023/2006.

6. Migration of chemicals, including reaction- and degradation products

(Adequate information relative to the substances used or products of degradation thereof for which restrictions or specifications are set out in specific regulations or directives)

7. "Dual-use" additives ${ }^{37}$
Information on trade date and supplier. Information from the supplier on e.g. production date, parameters and changes in composition.

Composition:

Background risk assessment data (scientific reports), calculations of migration limits, evaluation of exposure

Recipes on ingoing chemicals in the entire FCM Evaluation of potential degradation products and reaction products

Analysis:

Chemical $^{36}$

Organoleptic testing

GMP:

The critical points in the production and control measures in relation to these.

Migration limits from the legislation or calculated based on specific risk assessment.

Recipes including all chemicals used in the material. Documentation on the calculation of migration. Analysis or theoretical evaluation of possible reaction or degradation products.

Methods of analysis etc. see Annex IV Organoleptic testing: Method, e.g. training of panel and detailed results.

"Dual-use" additives and the listing of them in the Plastics regulation is based on EFSA's risk assessment of the substances as food additives. Migration must not result in exceeding the maximum levels in the food additives regulation. Information on compliance with the criteria for identity and purity for food additives. Migration testing, including results.

35 Recommended to be updated every 2 nd year. An older DoC can still be valid, this is subject to specific evaluation.

36 The chemical testing should be specified with analytical methods, detection limits, simulants and temperature used. See specific check points in Annex IV.

${ }^{37}$ Adequate information relative to the substances which are subject to a restriction in food, obtained by experimental data or theoretical calculation about the level of their specific migration and, where appropriate, purity criteria in accordance with Directives 2008/60/EC, 95/45/EC and 2008/84/EC to enable the user of these materials or articles to comply with the relevant EU provisions or, in their absence, with national provisions applicable to food. 
8. Specifications on the use of the material or article

9. Functional barrier

8. Labeling and instructions of use (i) type or types of food with which it is intended to be put in contact

(ii) time and temperature of treatment and storage in contact with the food

(iii) ratio of food contact surface area to volume used to establish the compliance of the material or article (for plastics).

Results from migration testing, documentation of test conditions covering the types of food, time and temperatures given in the instructions of use.

Results and methods of testing the functional barrier in contact with food types covered by the instructions of use.

When a functional barrier is used, confirmation that non-evaluated chemicals in layers on the outer side of the barrier do not migrate in quantities higher that $0.01 \mathrm{mg} / \mathrm{kg}$ to the food and that they are not carcinogenic, mutagenic or toxic to reproduction.

Results from migration testing and documentation of test conditions covering the types of food, time and temperatures given in the instructions of use. 



\section{Annex IV. Supporting documentation, analytical testing}

The supporting documentation for analytical testing of migration should include a range of information on the method of analysis, such as detection limits, the choice of test conditions, temperature or duration of contact and quality assurance of data. This information should be evaluated in details in order to control whether the information in the declaration of compliance is correct.

\begin{tabular}{|c|c|c|}
\hline Check point & Supporting documentation & Requested \\
\hline Test laboratory qualifications & $\begin{array}{l}\text { Is the test laboratory certified or accredited? This is not } \\
\text { a legal requirement, but laboratories must have a } \\
\text { quality assurance system. }\end{array}$ & \\
\hline Sampling & $\begin{array}{l}\text { Are the samples representative for the batch of FCM } \\
\text { covered by the declaration of compliance? }\end{array}$ & \\
\hline & Has the production process been modified or changed? & \\
\hline \multicolumn{3}{|l|}{ What is tested and how? } \\
\hline $\begin{array}{l}\text { Migration of chemicals } \\
\text { (starting substances) }\end{array}$ & $\begin{array}{l}\text { Which chemicals or materials have been tested? } \\
\text { Is set off from the outer side of a printed package tested? }\end{array}$ & \\
\hline & $\begin{array}{l}\text { Is the relevant part of the FCM tested? This is the part } \\
\text { which is in contact with the food under normal or fore- } \\
\text { seeable conditions of use. } \\
\text { E.g. gaskets in lids, area in contact, direct or indirect } \\
\text { contact } \\
\text { Is the data based on specific test conditions (e.g. from } \\
\text { regulation (EU) No 10/2011)? }\end{array}$ & \\
\hline $\begin{array}{l}\text { Migration of chemicals } \\
\text { (reaction and degradation } \\
\text { substances) }\end{array}$ & $\begin{array}{l}\text { Evaluation of possible reaction and degradation products, } \\
\text { e.g. from lacquers and printing inks. }\end{array}$ & \\
\hline
\end{tabular}




\begin{tabular}{|c|c|c|}
\hline Check point & Supporting documentation & Requested \\
\hline $\begin{array}{l}\text { Are test conditions used } \\
\text { correctly simulating contact } \\
\text { between FCM and food? } \\
\text { Test conditions should reflect } \\
\text { instructions of use of the FCM } \\
\text { in contact with food }\end{array}$ & $\begin{array}{l}\text { Test conditions in details, e.g. temperature, contact time, } \\
\text { simulants used or analysis in food. } \\
\text { Is there documentation for compliance between instruc- } \\
\text { tions of use, e.g. temperatures of the food, shelf life and } \\
\text { test conditions chosen? } \\
\text { If there are no instructions of use, testing should be } \\
\text { performed for "worst case" conditions. } \\
\text { For plastics, the test conditions in regulation (EU) No } \\
10 / 2011 \text { must be followed and documented. } \\
\text { For ceramics the test conditions in directive } 2005 / 31 / E C \text {, } \\
\text { which are implemented in national legislation, must be } \\
\text { followed and documented. }\end{array}$ & \\
\hline \multicolumn{3}{|l|}{ Methods of analysis } \\
\hline Method of analysis & $\begin{array}{l}\text { Are the methods of analysis used validated and is the } \\
\text { validation documented? } \\
\text { Is the method selective and specific (e.g. GC-MS and LC- } \\
\text { MS/MS)? } \\
\text { If the FCM is meant for long time contact, e.g. months, } \\
\text { accelerated tests can be used. } \\
\text { Is the quality of the analytical method used, acceptable? }\end{array}$ & \\
\hline $\begin{array}{l}\text { Performance parameters for } \\
\text { analysis }\end{array}$ & $\begin{array}{l}\text { Detection limits, LOD } \\
\text { Limit of quantification, LOQ }\end{array}$ & \\
\hline Calculation of results & $\begin{array}{l}\text { What is the uncertainty of the analysis and variation } \\
\text { between samples? } \\
\text { How is the calculation performed? } \\
\text { Consider whether the results should be given in } \mathrm{mg} / \mathrm{kg} \\
\text { or after surface volume in } \mathrm{dm}^{2} / \mathrm{kg} \text { food. }\end{array}$ & \\
\hline
\end{tabular}




\section{Annex V. Decision tree for requirements for declaration of compliance and supporting documentation}

The decision tree in this Annex is meant for guiding the responsible business operator through the evaluation of a specific FCM.

\begin{tabular}{|c|c|c|c|}
\hline Step & The material consist of & Requirement to be fulfilled & $\begin{array}{l}\text { Supplementary information/national } \\
\text { legislation }\end{array}$ \\
\hline 1 & $\begin{array}{l}\text { One layer? } \\
\text { Several layers? } \\
\text { Does the material } \\
\text { contain dual-use } \\
\text { additives? }\end{array}$ & $\begin{array}{l}\text { If a) } \\
\text { Requirements at steps } 3 \text { a-s } \\
\text { (type of material) } \\
\text { If b) } \\
\text { Requirements at step 3-a-s } \\
\text { (for the individual layers). } \\
\text { If c) } \\
\text { step } 2 \text { and 3-a-s }\end{array}$ & \\
\hline 2 & $\begin{array}{l}\text { Food additives, } \\
\text { flavourings } \\
\text { or other } \\
\text { chemicals } \\
\text { covered } \\
\text { by specific } \\
\text { regulation }\end{array}$ & $\begin{array}{l}\text { Overview of the EU require- } \\
\text { ments: } \\
\text { Food additives: } \\
\text { http://ec.europa.eu/food/ } \\
\text { food/fAEF/additives/ } \\
\text { eu_rules_en.htm } \\
\text { Flavourings: } \\
\text { http://ec.europa.eu/food/ } \\
\text { food/fAEF/flavouring/ } \\
\text { comm_legisl_en.htm }\end{array}$ & $\begin{array}{l}\text { Food additives are regulated in posi- } \\
\text { tive lists and permitted to be used in } \\
\text { specific foods with specific restrictions, } \\
\text { e.g. limits of content in the food, and } \\
\text { labelling requirements. }\end{array}$ \\
\hline $3-a$ & Adhesives & $\begin{array}{l}\text { Regulation (EC) No 1935/2004 } \\
\text { (Assessment of the } \\
\text { individual components) }\end{array}$ & Additives, solvents etc. \\
\hline
\end{tabular}

${ }^{38}$ A multilayer material can consist of layers of e.g. plastics, metal, printing inks, adhesives and surface coating. 


\begin{tabular}{|c|c|c|c|}
\hline Step & The material consist of & Requirement to be fulfilled & $\begin{array}{l}\text { Supplementary information/national } \\
\text { legislation }\end{array}$ \\
\hline $3-b$ & Cellulose regenerates & $\begin{array}{l}\text { Regulation (EC) No 1935/2004. } \\
\text { Commission Directive } \\
\text { 93/10/EEC as amended by } \\
\text { Directive } 93 / 111 / E C \text { and } \\
\text { Commission Directive } \\
\text { 2004/14/EC. This sets a } \\
\text { positive list of authorized } \\
\text { substances and the conditions } \\
\text { under which they can be } \\
\text { used. }\end{array}$ & $\begin{array}{l}\text { Polymers, additives } \\
\text { Livsmedelsverkets föreskrifter (LIVSFS } \\
\text { 2011:7) om material och produkter } \\
\text { avsedda att komma I kontakt med } \\
\text { livsmedel }\end{array}$ \\
\hline $3-c$ & Ceramics & $\begin{array}{l}\text { Regulation (EC) No 1935/2004. } \\
\text { Council Directive } 84 / 500 / E E C \\
\text { as amended by Directive } \\
2005 / 31 / \text { EC. Maximum levels } \\
\text { on lead and cadmium } \\
+ \text { Assessment of the individual } \\
\text { components. }\end{array}$ & $\begin{array}{l}\text { Clay, silicium oxide, additives, surface } \\
\text { coating } \\
\text { Livsmedelsverkets föreskrifter (LIVSFS } \\
\text { 2011:7) om material och produkter } \\
\text { avsedda att komma I kontakt med } \\
\text { livsmedel. } \\
\text { NO: National maximum levels on } \\
\text { migration of lead, cadmium and } \\
\text { barium. }\end{array}$ \\
\hline $3-d$ & Cork & $\begin{array}{l}\text { Regulation (EC) No } 1935 / 2004 \text {. } \\
\text { (Assessment of the individual } \\
\text { components) }\end{array}$ & $\begin{array}{l}\text { Bark of Querqus suber, possibly } \\
\text { additives and surface coatings }\end{array}$ \\
\hline $3-e$ & Glass & $\begin{array}{l}\text { Regulation (EC) No } 1935 / 2004 \text {. } \\
\text { (Assessment of the individual } \\
\text { components) }\end{array}$ & $\begin{array}{l}\text { DK: National maximum levels on } \\
\text { migration of lead and cadmium. } \\
\text { NO: National maximum levels on } \\
\text { migration of lead and cadmium. }\end{array}$ \\
\hline $3-g$ & Leather & $\begin{array}{l}\text { Regulation (EC) No 1935/2004. } \\
\text { (Assessment of the individual } \\
\text { components) }\end{array}$ & Hide, possibly additives. \\
\hline $3-h$ & Metals and alloys & $\begin{array}{l}\text { Regulation (EC) No } 1935 / 2004 \text {. } \\
\text { (Assessment of the individual } \\
\text { components) }\end{array}$ & $\begin{array}{l}\text { Metals, possibly surface coatings and } \\
\text { printing inks, Nordic Guideline on } \\
\text { metals and alloys: } \\
\text { http://dx.doi.org/10.6027/TN2015-522 }\end{array}$ \\
\hline $3-i$ & $\begin{array}{l}\text { Paper and board, } \\
\text { recycled }\end{array}$ & Regulation (EC) No 1935/2004 & $\begin{array}{l}\text { Fibres, additives and contaminants like } \\
\text { chemicals must be considered. It is } \\
\text { recommended only to use recycled } \\
\text { paper and board for contact with food } \\
\text { types that have a shell or is peeled } \\
\text { before ingestion. }\end{array}$ \\
\hline $3-j$ & Paper and board, virgin & Regulation (EC) No 1935/2004 & $\begin{array}{l}\text { Fibres and additives must be } \\
\text { considered. } \\
\text { Nordic guideline - paper and board: } \\
\text { http://dx.doi.org/10.6027/TN2008-515 }\end{array}$ \\
\hline
\end{tabular}




\begin{tabular}{|c|c|c|c|}
\hline Step & The material consist of & Requirement to be fulfilled & $\begin{array}{l}\text { Supplementary information/national } \\
\text { legislation }\end{array}$ \\
\hline $3-k$ & Plastics & $\begin{array}{l}\text { Regulation (EC) No 1935/2004 } \\
\text { Regulation (EU) No } 10 / 2011^{39} \\
\text { Regulation (EC) No } 282 / 2008\end{array}$ & $\begin{array}{l}\text { Positive list with monomers and } \\
\text { additives for plastics. }\end{array}$ \\
\hline $3-1$ & Printing inks & $\begin{array}{l}\text { Regulation (EC) No 1935/2004 } \\
\text { (Assessment of the } \\
\text { individual components ) }\end{array}$ & $\begin{array}{l}\text { Colours, pigments, additives, solvents, } \\
\text { processing aids. } \\
\text { Nordic guideline Food contact materi- } \\
\text { als and articles: Printing Inks: } \\
\text { http://dx.doi.org/10.6027/TN2012-521 }\end{array}$ \\
\hline $3-m$ & Rubber & $\begin{array}{l}\text { Regulation (EC) No 1935/2004 } \\
\text { (Assessment of } \\
\text { the individual components) }\end{array}$ & $\begin{array}{l}\text { Polymers and additives must be } \\
\text { considered. Maximum level of nitros- } \\
\text { amines in soothers and baby bottles. }\end{array}$ \\
\hline $3-n$ & Silicones & $\begin{array}{l}\text { Regulation (EC) No } 1935 / 2004 \\
\text { (Assessment of the individual } \\
\text { components) }\end{array}$ & $\begin{array}{l}\text { Polymers and additives must be } \\
\text { considered. }\end{array}$ \\
\hline $3-0$ & Stone & $\begin{array}{l}\text { Regulation (EC) No } 1935 / 2004 \\
\text { (Assessment of the individual } \\
\text { components) }\end{array}$ & $\begin{array}{l}\text { Different stones (minerals), possibly } \\
\text { with surface coatings. }\end{array}$ \\
\hline $3-p$ & $\begin{array}{l}\text { Surface coatings, } \\
\text { including lacquers and } \\
\text { heavy duty coatings }\end{array}$ & $\begin{array}{l}\text { Regulation (EC) No 1935/2004 } \\
\text { (Assessment of the individual } \\
\text { components) }\end{array}$ & $\begin{array}{l}\text { Additives, solvents etc. must be } \\
\text { considered. }\end{array}$ \\
\hline $3-q$ & Textiles & $\begin{array}{l}\text { Regulation (EC) No } 1935 / 2004 \\
\text { (Assessment of the individual } \\
\text { components) }\end{array}$ & $\begin{array}{l}\text { Cotton, linen, wool, possibly with } \\
\text { additives. }\end{array}$ \\
\hline 3-s & Wood & $\begin{array}{l}\text { Regulation (EC) No } 1935 / 2004 \\
\text { (Assessment of the individual } \\
\text { components) }\end{array}$ & $\begin{array}{l}\text { Different wood species, possibly with } \\
\text { surface coatings and printing inks. } \\
\text { Genuine Nordic species like pine, beech, } \\
\text { oak and birch can be used for food } \\
\text { contact, for other species assessment of } \\
\text { the individual species must be per- } \\
\text { formed. }\end{array}$ \\
\hline
\end{tabular}

${ }^{39}$ In the transitional period the test conditions in the previous legislation for plastics can still be used until 31st December 2015. 
Nordic Council of Ministers

Ved Stranden 18

DK-1061 Copenhagen K

www.norden.org

\section{Nordic checklist food contact materials}

Documentation of compliance with the legislation is a corner stone in the control of food contact materials (FCM). In-house control is an important pre-requisite to limit contamination from FCM and shall be based on the declaration of compliance and supporting documentation at the responsible business operators in the supply chain. The goal of this project was to develop a Nordic checklist on documentation of compliance for FCM. The Nordic checklist contains several templates. The different templates provide check points on the minimum requirements for a declaration of compliance for all types of materials. The templates are meant to be used by industry and trade as guidance for drafting a declaration of compliance. Furthermore, the check lists are also meant to be tools for the public food and FCM inspection.

TemaNord 2015:569

ISBN 978-92-893-4316-9 (PRINT)

ISBN 978-92-893-4318-3 (PDF)

ISBN 978-92-893-4317-6 (EPUB)

ISSN 0908-6692 